\title{
Enhanced T cell recovery in HIV-1-infected adults through IL-7 treatment
}

\author{
Yves Levy, ${ }^{1}$ Christine Lacabaratz, ${ }^{1}$ Laurence Weiss, ${ }^{2}$ Jean-Paul Viard, ${ }^{3}$ Cecile Goujard, ${ }^{4}$ \\ Jean-Daniel Lelièvre, ${ }^{1}$ François Boué, ${ }^{5}$ Jean-Michel Molina, ${ }^{6}$ Christine Rouzioux, ${ }^{3}$ \\ Véronique Avettand-Fénoêl, ${ }^{3}$ Thérèse Croughs, ${ }^{7}$ Stéphanie Beq, ${ }^{7}$ Rodolphe Thiébaut, ${ }^{8}$ \\ Geneviève Chêne, ${ }^{8}$ Michel Morre, ${ }^{7}$ and Jean-François Delfraissy ${ }^{4}$
}

\begin{abstract}
1INSERM U955, Université Paris 12, and Assistance Publique-Hôpitaux de Paris (AP-HP), Groupe Henri-Mondor Albert-Chenevier, Immunologie Clinique, Creteil, France. ${ }^{2}$ Université Paris Descartes and AP-HP, Hôpital Européen Georges Pompidou, Paris, France. ${ }^{3}$ AP-HP, Hôpital Necker-Enfants-Malades, Paris, France. ${ }^{4}$ INSERM U802, Université Paris 11, AP-HP, Hôpital du Kremlin Bicêtre, Kremlin Bicetre, France. ${ }^{5}$ AP-HP, Hôpital Antoine Béclère, Clamart, France. ${ }^{6}$ AP-HP, Hôpital Saint-Louis, Paris, France. ${ }^{7}$ Cytheris, Issy-les-Moulineaux, France. 8INSERM U897, Université Victor Segalen Bordeaux 2, ISPED, Bordeaux, France.
\end{abstract}

\begin{abstract}
HIV infection results in $\mathrm{CD}^{+} \mathrm{T}$ cell deficiency, but efficient combination antiretroviral therapy (c-ART) restores $T$ cells and decreases morbidity and mortality. However, immune restoration by c-ART remains variable, and prolonged $\mathrm{T}$ cell deficiency remains in a substantial proportion of patients. In a prospective openlabel phase I/IIa trial, we evaluated the safety and efficacy of administration of the T cell regulator IL-7. The trial included $13 \mathrm{c}$-ART-treated HIV-infected patients whose $\mathrm{CD}^{+}$cell counts were between 100 and 400 cells/ $/ \mu \mathrm{l}$ and plasma HIV RNA levels were less than 50 copies $/ \mathrm{ml}$. Patients received a total of 8 subcutaneous injections of 2 different doses of recombinant human IL-7 (rhIL-7; 3 or $10 \mu \mathrm{g} / \mathrm{kg}$ ) 3 times per week over a 16-day period. rhIL-7 was well tolerated and induced a sustained increase of naive and central memory CD4 ${ }^{+}$and $\mathrm{CD8}^{+} \mathrm{T}$ cells. In the highest dose group, 4 patients experienced transient increases in viral replication. However, functional assays showed that the expanded T cells responded to HIV antigen by producing IFN- $\gamma$ and/or IL-2. In conclusion, in lymphopenic HIV-infected patients, rhIL-7 therapy induced substantial functional and quantitative changes in T cells for 48 weeks. Therefore, patients may benefit from intermittent therapy with IL-7 in combination with c-ART.
\end{abstract}

\section{Introduction}

Infection with HIV is characterized by chronic T cell depletion and increased risk of illness and opportunistic infection. Effective treatment of HIV infection with combination antiretroviral therapy (c-ART) suppresses viral replication, leading to recovery of $\mathrm{CD}^{+} \mathrm{T}$ cells in the majority of individuals (1). This leads to a significant improvement in immune functions and to a dramatic reduction in the incidence of both HIV-related mortality and AIDS-defining events $(2,3)$. Nevertheless, long-term suppressive c-ART remains associated with a persistent qualitative defect of immune function and does not result in normalization of $\mathrm{CD}^{+}$ $T$ cell counts in a substantial proportion of individuals (4-6). There is considerable variability among individuals in the extent of $\mathrm{CD}^{+}$ $\mathrm{T}$ cell reconstitution, ranging from those who achieve normal levels of $\mathrm{CD}^{+}$cells to those whose $\mathrm{T}$ cell counts remain persistently low (7). Moreover, despite successful therapy, recent studies show that life expectancy of these HIV-infected patients is still shorter than that of HIV-negative age- and gender-matched controls (8). Death amongst these patients is now increasingly attributed to non-AIDS conditions typical of aging, including cardiovascular disease, cancer, and end-stage liver and renal diseases, which occur at an excessive rate in HIV-infected patients compared with the general population (9-12).

Conflict of interest: M. Morre is the founder and Chief Executive Officer of Cytheris, and T. Croughs and S. Beq are employees of Cytheris.

Nonstandard abbreviations used: c-ART, combination antiretroviral therapy; IL-7R $\alpha$, IL-7 receptor $\alpha$ chain; IQR, interquartile range; rhIL-7, recombinant human IL-7; RTE, recent thymic emigrant; SEB, staphylococcal enterotoxin B.

Citation for this article: J. Clin. Invest. 119:997-1007 (2009). doi:10.1172/JCI38052.
In addition to traditional risk factors, several factors, such as uncontrolled virological replication and chronic immune activation, could cause these serious non-AIDS events. Recent cohort studies show that the level of immune competence may be highly relevant to the pathogenesis of these conditions, even in patients who have undetectable viral load $(5,11)$. Time spent at a lower $\mathrm{CD}^{+} \mathrm{T}$ cell count, or a poor initial recovery of $\mathrm{CD} 4^{+} \mathrm{T}$ cells, after initiation of c-ART contributes to greater morbidity and mortality $(9,10,12-14)$. The ability of c-ART alone to restore immunocompetence and mitigate the underlying harmful aspects of chronic immune activation appears incomplete $(15,16)$. Therefore, development of complementary approaches able to compensate for the limitations of c-ART would be of interest.

The immune system is subjected to homeostatic regulation that ensures maintenance of a more or less constant total number of lymphocytes in the periphery. This is achieved through complex cellular interactions that control cell proliferation, differentiation, and death through numerous cytokines and interactions with the environment (17). This equilibrium is severely compromised in situations characterized by profound acute or chronic T cell depletion, such as immunosuppressive treatments, irradiation, or HIV infection (18). In these situations, T cell numbers will return to normal values through thymic-independent antigen-driven peripheral expansion and/or the generation of lymphocytes from hematopoietic stem/progenitor cells. A therapeutic approach aimed at accelerating the recovery of the human $\mathrm{T}$ cell compartment and at improving the effectiveness of the immune system could represent an efficient immune-based therapy for lymphopenic conditions.

IL-7 is a cytokine playing an important role in T cell homeostasis (19) and is essential for $\mathrm{T}$ cell development in mice and 


\section{Table 1}

Baseline characteristics of study population

\begin{tabular}{|c|c|c|c|}
\hline Measurement & $3-u g / k g$ dose & $10-\mu \mathrm{g} / \mathrm{kg}$ dose & Overall \\
\hline$n$ & 6 & 8 & 14 \\
\hline Age (yr) & $46(33 ; 65)$ & $46(29 ; 61)$ & $46(29 ; 65)$ \\
\hline $\mathrm{BMI}\left(\mathrm{kg} / \mathrm{cm}^{2}\right)^{\mathrm{A}}$ & $24.53(19.47 ; 27.99)$ & $22.28(18.75 ; 33.30)$ & $23.52(18.75 ; 33.30)$ \\
\hline Time since HIV infection $(\mathrm{yr})^{\mathrm{A}}$ & $8(4 ; 15)$ & $7(3 ; 20)$ & $8(3 ; 20)$ \\
\hline Time since c-ART (yr) ${ }^{A}$ & $8(4 ; 15)$ & $6(2 ; 16)$ & $7(2 ; 16)$ \\
\hline Total CD4+ T cells, prior $6 \mathrm{mo}(\mathrm{U} / \mu \mathrm{l})^{\mathrm{B}}$ & $214(127 ; 275)$ & $266(142,316)$ & - \\
\hline Total CD4+ T cells $(\mathrm{U} / \mu \mathrm{l})$ & $217(107 ; 289)$ & $237(160 ; 312)$ & $230(107 ; 312)$ \\
\hline Total CD8+ T cells $(\mathrm{U} / \mu \mathrm{l})$ & $848(249 ; 1,245)$ & $574(226 ; 790)$ & $606(226 ; 1,245)$ \\
\hline Nadir CD4+ T cell $(\mathrm{U} / \mu \mathrm{l})$ & $44(1 ; 69)$ & $45(6 ; 137)$ & $44(1 ; 137)$ \\
\hline HIV-1 DNA ( $\log _{10}$ copies $/ 10^{6}$ CD $4+$ cells) & 3.3 (ND; 3.9) & 3.3 (ND; 4.5) & 3.3 (ND; 4.5$)$ \\
\hline HIV-1 mRNA <50 copies/ml $(n)$ & 6 & 7 & 13 \\
\hline HIV-1 mRNA >50 copies/ml $(n)$ & 0 & $1^{\mathrm{C}}$ & 1 \\
\hline
\end{tabular}

Median values are shown, with minimum and maximum values shown in parentheses. ${ }^{A}$ Derived data. ${ }^{\mathrm{B} T o t a l}$ cells within the last 6 mo prior to study entry. CPatient withdrawn after a single dose with $130 \mathrm{copies} / \mathrm{ml}$ (protocol deviation). ND, not detectable (for HIV-1 RNA, the limit of quantification was $50 \mathrm{copies} / \mathrm{ml}$ ).

absolute $\mathrm{CD}^{+} \mathrm{T}$ cell count within the last $6 \mathrm{mo}$ ( 3 time points) prior to the study entry was 214 and 265 cells/ $\mu \mathrm{l}$ for the $3-$ and $10-\mu \mathrm{g} / \mathrm{kg}$ dose, respectively (Table 1$)$. The median absolute $\mathrm{CD} 4^{+} \mathrm{T}$ cell count at baseline (equal to the combined value at screening and $0 \mathrm{~d}$ ) was 217 cells/ $\mu \mathrm{l}$ for the $3-\mu \mathrm{g} / \mathrm{kg}$ dose and 239 cells $/ \mu \mathrm{l}$ for the $10-\mu \mathrm{g} / \mathrm{kg}$ dose, confirming the defect in the quantitative immune reconstitution. At $28 \mathrm{~d}$, absolute $\mathrm{CD}^{+}, \mathrm{CD}^{+}$, and $\mathrm{CD}^{+} \mathrm{T}$ cell counts increased dramatically in all patients (Figure 1A). Patients receiving the $3-\mu \mathrm{g} / \mathrm{kg}$ dose experienced a median gain of $118 \mathrm{CD}^{+}{ }^{+} \mathrm{T}$ cells/ $\mu \mathrm{l}$ (68\% increase; interquartile range [IQR], 88 to 215 cells $/ \mu 1 ; P=0.03$, Wilcoxon test), and patients receiving the

humans (20-23). IL-7 modulates thymic output and mediates the expansion and survival of naive and memory $\mathrm{T}$ cells $(20,21$, 23-25). IL-7 also inhibits the apoptosis of $\mathrm{CD}^{+}$and $\mathrm{CD}^{+} \mathrm{T}$ cells from HIV-infected patients in vitro (26). These findings provide a rationale for considering IL-7 as an agent for immune reconstitution in HIV infection (27).

We report here findings of a prospective multicenter open-label phase I/IIa study designed specifically to assess the safety and immunological effects of repeated administration of recombinant human IL-7 (rhIL-7) therapy in chronically HIV-infected subjects with persistently low $\mathrm{CD}^{+} \mathrm{T}$ cell counts despite virologic suppression under c-ART. We showed that IL-7 administration was well tolerated and induced a significant, dose-dependent increase of naive and central memory $\mathrm{CD}^{+}$and $\mathrm{CD}^{+} \mathrm{T}$ cells. In vitro assays showed that these cells were functional and responded to HIV antigen by producing cytokines.

\section{Results}

Study design and participants. We screened 17 patients and included 14 in this prospective open-label multicenter study of rhIL-7 therapy. Eligible patients had a $\mathrm{CD}^{+} \mathrm{T}$ cell count of $100-400$ cells $/ \mu \mathrm{l}$ and plasma HIV RNA levels less than 50 copies/ml for at least 6 mo while receiving a combination of antiretroviral drugs for at least 12 mo. Patients received s.c. injections of rhIL-7 (see Methods) every other day for a total of 8 doses over $16 \mathrm{~d}$. Visits for safety and immunological efficacy were made at $7,14,21,28$, and $35 \mathrm{~d}$ and $12 \mathrm{wk}$. An extended follow-up period lasted until $48 \mathrm{wk}$.

We enrolled 6 patients at the $3-\mu \mathrm{g} / \mathrm{kg}$ dose and 8 patients at the $10-\mu \mathrm{g} / \mathrm{kg}$ dose. The baseline characteristics of patients are listed in Table 1 . At the $3-\mu \mathrm{g} / \mathrm{kg}$ dose, all patients received 8 injections. At the $10-\mu \mathrm{g} / \mathrm{kg}$ dose, 6 patients received 8 injections, 1 patient received 7 injections because of a dose-limiting toxicity event after the seventh injection, and 1 patient received only 1 injection. The sum of the doses injected per patient was $24 \mu \mathrm{g} / \mathrm{kg}$ for the $3-\mu \mathrm{g} / \mathrm{kg}$ dose and $80 \mu \mathrm{g} / \mathrm{kg}$ for the $10-\mu \mathrm{g} / \mathrm{kg}$ dose. All patients completed $12 \mathrm{wk}$ of follow-up as well as the 48-wk extended follow-up.

rbIL-7 therapy induces a significant increase of $T$ cells in a dose-dependent manner. The impact of IL-7 administration on the absolute CD $4^{+}$ and $\mathrm{CD}^{+}$counts is shown in Figure $1 \mathrm{~A}$ and Table 2. The median $10-\mu \mathrm{g} / \mathrm{kg}$ dose showed a median gain of $576 \mathrm{CD}^{+} \mathrm{T}$ cells $/ \mu \mathrm{l}(212 \%$ increase; IQR, 442 to 695 cells $/ \mu l ; P=0.02$, Wilcoxon test). At the same time points, the median increase in $\mathrm{CD}^{+} \mathrm{T}$ cell counts was 282 cells/ $\mu \mathrm{l}$ for the $3-\mu \mathrm{g} / \mathrm{kg}$ dose (45\% increase; IQR, 379 to 1,097 cells $/ \mu \mathrm{l} ; P=0.03)$ and 996 cells $/ \mu \mathrm{l}$ for the $10-\mu \mathrm{g} / \mathrm{kg}$ dose $(206 \%$ increase; IQR, 1,059 to 2,107 cells $/ \mu \mathrm{l} ; P=0.02$ ). We also evaluated the kinetics of $\mathrm{CD} 4^{+} \mathrm{T}$ cell increases. At $7 \mathrm{~d}$, patients receiving the 3 - and $10-\mu \mathrm{g} / \mathrm{kg}$ doses experienced a median increase of $92 \mathrm{CD}^{+}$ $\mathrm{T}$ cells $/ \mu \mathrm{l}\left(50 \%\right.$ increase) and $471 \mathrm{CD} 4^{+} \mathrm{T}$ cells $/ \mu \mathrm{l}$ (170\% increase), respectively. $\mathrm{CD}^{+} \mathrm{T}$ cell counts peaked at $21 \mathrm{~d}$ in both treatment groups and reached a median of 458 cells $/ \mathrm{ml}$ (109\% increase) at $3 \mu \mathrm{g} / \mathrm{kg}$ and 911 cells $/ \mathrm{ml}$ (308\% increase) at $10 \mu \mathrm{g} / \mathrm{kg}$. Consequently, the time to reach a $\mathrm{CD}^{+}$cell count of up to $500 \mathrm{cells} / \mu \mathrm{l}$ after the first administration of IL-7 was within a median of 21 and $7 \mathrm{~d}$ in patients receiving doses of 3 and $10 \mu \mathrm{g} / \mathrm{kg}$, respectively. Finally, the magnitude of the $\mathrm{CD} 4^{+} \mathrm{T}$ cell gain at $12 \mathrm{wk}$ was strongly correlated with $\mathrm{CD}^{+} \mathrm{T}$ cell counts at baseline (Spearman $r^{2}, 0.432$; $P=0.01$; Figure 2).

A slight decrease of circulating mature B cells was noted at $14 \mathrm{~d}$ in patients from both dose levels (Figure $1 \mathrm{~B}$ and Table 2). No increase of pro- $\mathrm{B} \mathrm{CD} 34^{+} \mathrm{CD} 19^{+} \mathrm{B}$ cells was noted in the periphery regardless of the dose of rhIL-7 administered (Figure 1B and Table 2). A substantial percentage of mature B cells expressed CD10 antigen (Figure 1B), a recently described phenotype of transitional B cells (28). No significant changes in $\mathrm{CD}^{-} \mathrm{CD}^{-} 6^{+} \mathrm{NK}$ cell counts were noted throughout the study in patients treated with the $3-\mu \mathrm{g} / \mathrm{kg}$ dose, but a significant increase at $14 \mathrm{~d}$ (additional 58 cells/ $\mu \mathrm{l}$ ) that persisted at $28 \mathrm{~d}$ was observed in subjects treated with the $10-\mu \mathrm{g} / \mathrm{kg}$ dose (Figure $1 \mathrm{C}$ and Table 2). In addition, a persistent increase of NKT cells $\left(\mathrm{CD}^{+} \mathrm{CD} 56^{+}\right)$was also noted in these same patients (additional 71 cells/ $\mu \mathrm{l}$ at $14 \mathrm{~d}$; Figure $1 \mathrm{C}$ and Table 2). These results showed that in HIV-infected patients, rhIL-7 therapy preferentially increases the number of $\mathrm{CD}^{+}$and $\mathrm{CD}^{+} \mathrm{T}$ cells in a dose-dependent manner.

Sustained effects of rbIL-7 therapy on lymphocyte cell counts. Beyond $28 \mathrm{~d}$, all patients were included in the long-term survey of this study. Although $\mathrm{CD}^{+} \mathrm{T}$ cells slightly decreased beyond $28 \mathrm{~d}$, cell counts remained significantly higher than baseline values. Median $\mathrm{CD}^{+}$ $\mathrm{T}$ cell counts in patients from the $3 \mu \mathrm{g} / \mathrm{kg}$ dose were 329 cells $/ \mu \mathrm{l}$ at $12 \mathrm{wk}$ (range, 177 to 358 cells/ $\mu \mathrm{l} ; 54 \%$ increase over baseline), 
A

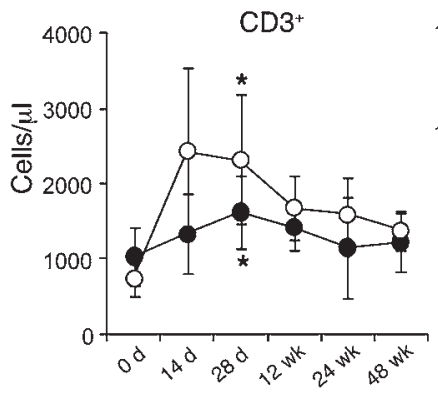

B

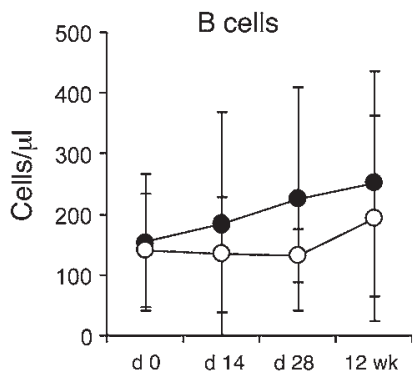

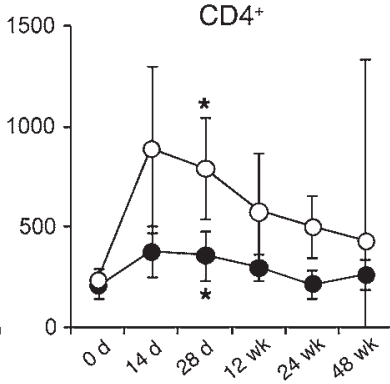
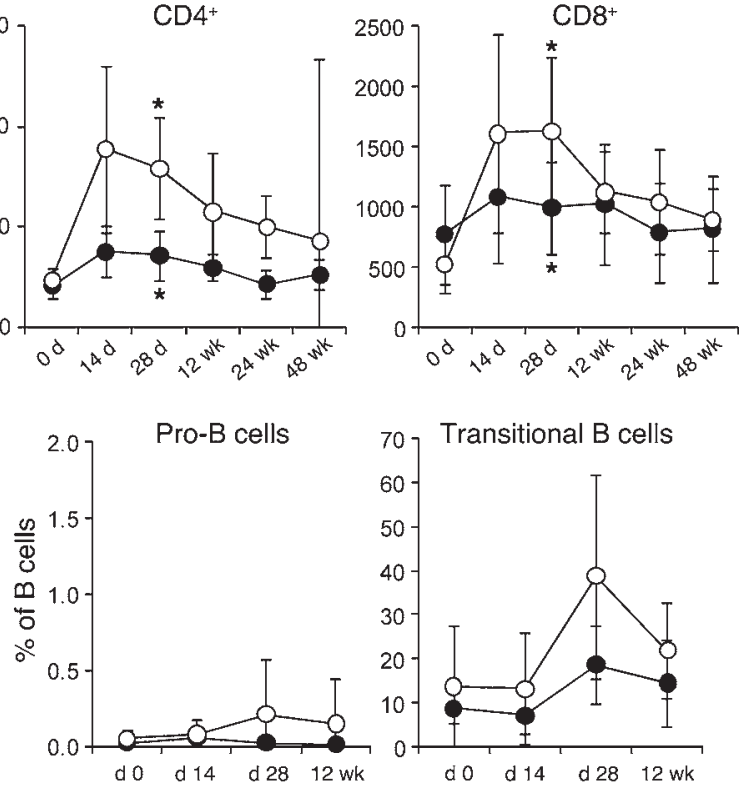

C

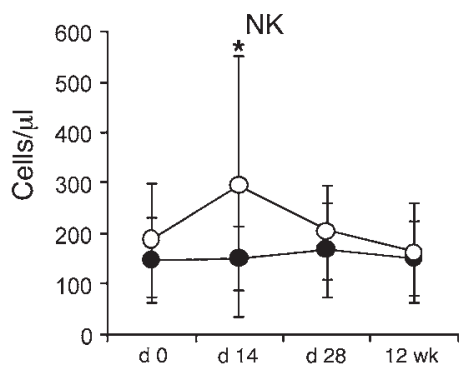

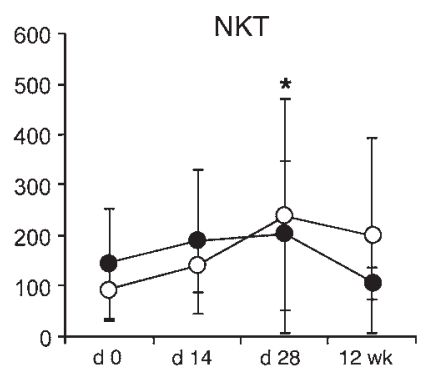

$\mathrm{CD}^{+}$
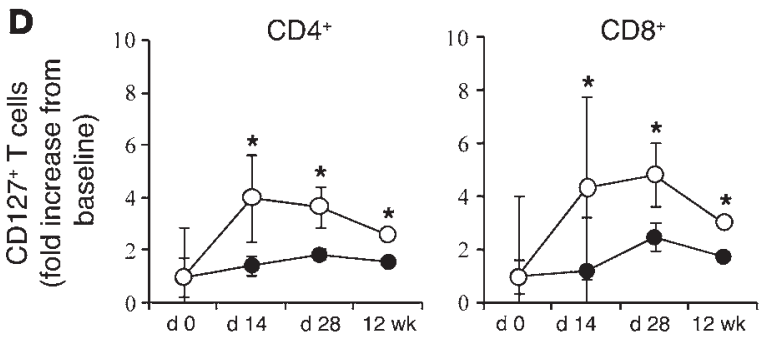

252 cells/ $\mu$ lat $24 \mathrm{wk}$ (range, 116 to 271 cells/ $\mu \mathrm{l} ; 21 \%$ increase over baseline), and 282 cells/ $\mu \mathrm{l}$ at $48 \mathrm{wk}$ (range, 152 to 346 cells $/ \mu \mathrm{l}$; $28 \%$ increase over baseline; $P<0.0001$, Friedman test). In patients given the $10-\mu \mathrm{g} / \mathrm{kg}$ dose, median $\mathrm{CD}^{+} \mathrm{T}$ cell counts were 575 cells/ $\mu \mathrm{l}$ at $12 \mathrm{wk}$ (range, 237 to 804 cells/ $\mu \mathrm{l} ; 130 \%$ increase over baseline), 525 cells/ $\mu \mathrm{l}$ at $24 \mathrm{wk}$ (range, 230 to $696 \mathrm{cells} / \mu \mathrm{ul}$; $95 \%$ increase over baseline), and 403 cells $/ \mu \mathrm{l}$ at $48 \mathrm{wk}$ (range, 213 to 654 cells $/ \mu \mathrm{l} ; 75 \%$ increase over baseline; $P<0.0001$, Friedman test). Similarly, and as shown in Figure $1 \mathrm{~A}, \mathrm{CD}^{+} \mathrm{T}$ cell counts also remained significantly higher than baseline values throughout the study. By 12, 24, and $48 \mathrm{wk}$, median percentages of $\mathrm{CD}^{+} \mathrm{T}$ cell counts were still $121 \%, 55 \%$, and $58 \%$ above baseline, respectively, in patients given the $10-\mu \mathrm{g} / \mathrm{kg}$ dose $(P<0.0001$, Friedman test). These results showed that the immunological effects of rhIL-7 were sustained and that total $\mathrm{CD}^{+}$and $\mathrm{CD}^{+}$ $\mathrm{T}$ cell counts remained elevated for up to $45 \mathrm{wk}$ after discontinuation of rhIL-7 administration.
Naive and central memory Tcell populations are preferentially increased by rbIL-7 therapy. We investigated the effects of rhIL-7 therapy on the different subsets of $\mathrm{CD} 4^{+}$and $C D 8^{+} \mathrm{T}$ cells using CD45RA with $\mathrm{CD} 27$ and CD28 markers for the definition of naive, central memory, effector memory, effector, and terminally differentiated effector $\mathrm{CD}^{+}$and $\mathrm{CD}^{+} \mathrm{T}$ cells (see Methods). As shown in Figure 3 and Table 2 , at $28 \mathrm{~d}$, rhIL-7 therapy administered at the $3-\mu \mathrm{g} / \mathrm{kg}$ dose preferentially expanded naive and central memory $\mathrm{CD}^{+}$ $\mathrm{T}$ cells $(P=0.03$ versus baseline for both comparisons). Changes in naive, central memory, and effector memory cells were significantly different in patients treated with $10 \mu \mathrm{g} / \mathrm{kg}$ rhIL-7 and had already achieved significance at $14 \mathrm{~d}(P<0.03$ versus baseline for all comparisons). At $28 \mathrm{~d}$, mean absolute counts increased from 45 to 183 cells $/ \mu$ in the naive subset, from 126 to 422 cells/ $\mu l$ in the central memory subset, and from 51 to 166 cells/ $\mu$ in the effector memory subset. In addition, these changes remained significant at $12 \mathrm{wk}(P=0.03)$. As noted for patients treated with the lower 


\section{Table 2}

Changes from baseline characteristics

\begin{tabular}{|c|c|c|c|c|c|c|}
\hline \multirow[t]{2}{*}{ Measurement } & \multicolumn{3}{|c|}{$3-\mu \mathrm{g} / \mathrm{kg}$ dose } & \multicolumn{3}{|c|}{$10-\mu \mathrm{g} / \mathrm{kg}$ dose } \\
\hline & $14 \mathrm{~d}$ & $28 \mathrm{~d}$ & 12 wk & $14 \mathrm{~d}$ & $28 \mathrm{~d}$ & $12 w k$ \\
\hline \multicolumn{7}{|l|}{$\mathrm{CD4}^{+} \mathrm{T}$ cells } \\
\hline Total & $158^{A}(83 ; 215)$ & $118^{A}(81 ; 293)$ & $101^{A}(35 ; 124)$ & $752^{A}(207 ; 1,152)$ & $576^{A}(186 ; 793)$ & $385^{A}(77 ; 513)$ \\
\hline$N^{B}$ & $8^{A}(4 ; 39)$ & $7^{A}(3 ; 84)$ & $6^{A}(-5 ; 40)$ & $91^{A}(57 ; 284)$ & $108^{A}(28 ; 301)$ & $71^{\mathrm{A}}(32 ; 143)$ \\
\hline $\mathrm{CM}^{\mathrm{C}}$ & $73^{\mathrm{A}}(50 ; 155)$ & $44^{A}(26 ; 160)$ & $20^{A}(-43 ; 92)$ & $364^{\mathrm{A}}(130 ; 772)$ & $349^{A}(92 ; 426)$ & $184^{\mathrm{A}}(28 ; 377)$ \\
\hline EMD & $44(21 ; 63)$ & $46(37 ; 93)$ & $35^{A}(6 ; 125)$ & $140^{A}(9 ; 319)$ & $137^{A}(29 ; 167)$ & $58^{A}(18 ; 81)$ \\
\hline $\mathrm{EE}^{\mathrm{E}}$ & $24(1 ; 26)$ & $6(-9 ; 29)$ & $5(-2 ; 18)$ & $12^{A}(0 ; 26)$ & $2^{A}(0 ; 25)$ & $0(0 ; 12)$ \\
\hline $\mathrm{TEF}^{\mathrm{F}}$ & $0(-11 ; 7)$ & $0(-9 ; 19)$ & $0(-17 ; 18)$ & $2(-1 ; 11)$ & $0(-11 ; 35)$ & $1(-17 ; 47)$ \\
\hline RTE $^{\mathrm{G}}$ & $7(-4 ; 24)$ & $7^{A}(2 ; 71)$ & $5(-2 ; 29)$ & $g^{A}(3 ; 9)$ & $17^{A}(0 ; 51)$ & $6(-2 ; 13)$ \\
\hline Activated $(\%)^{\mathrm{H}}$ & $2(-1 ; 2)$ & $1(0 ; 4)$ & $0(-3 ; 2)$ & $0(-1 ; 2)$ & $0(-1 ; 6)$ & $-1(-2 ; 1)$ \\
\hline $\mathrm{Ki} 67+(\%)$ & $2^{A}(-3 ; 8)$ & $-1(-2 ; 2)$ & $-1(-2 ; 1)$ & $3^{A}(0 ; 4)$ & $-1(-2 ;-1)$ & $0(-2 ; 2)$ \\
\hline \multicolumn{7}{|l|}{ CD8+ $T$ cells } \\
\hline Total & $290^{A}(96 ; 666)$ & $494^{\mathrm{A}}(-662 ; 664)$ & $203^{A}(65 ; 555)$ & $1,040^{A}(191 ; 2,194)$ & $996^{A}(534 ; 1,783)$ & $464^{A}(416 ; 848)$ \\
\hline$N^{B}$ & $80(63 ; 231)$ & $118(-46 ; 329)$ & $130(30 ; 189)$ & $458^{A}(62 ; 1371)$ & $491^{\mathrm{A}}(162 ; 1,520)$ & $318^{A}(109 ; 575)$ \\
\hline $\mathrm{CM}^{\mathrm{C}}$ & $125(27 ; 269)$ & $36(-301 ; 282)$ & $55(35 ; 199)$ & $224^{A}(31 ; 1,562)$ & $328^{A}(67 ; 723)$ & $165^{A}(-21 ; 509)$ \\
\hline $\mathrm{EM}^{\mathrm{D}}$ & $-1(-21 ; 4)$ & $-2(-57 ; 28)$ & $9(-4 ; 81)$ & $7(-12 ; 49)$ & $12(-11 ; 178)$ & $13(-11 ; 61)$ \\
\hline $\mathrm{E}^{\mathrm{E}}$ & $50(3 ; 77)$ & $-8(-163 ; 191)$ & $-2(-38 ; 105)$ & $20^{A}(-32 ; 199)$ & $22(-29 ; 198)$ & $-6(-77 ; 71)$ \\
\hline TEF & $32(-71 ; 76)$ & $88(-190 ; 112)$ & $10(-10 ; 28)$ & $35(-60 ; 55)$ & $42(-51 ; 131)$ & $46(-54 ; 90)$ \\
\hline Activated $(\%)^{\mathrm{H}}$ & $0(-3 ; 10)$ & $1(-2 ; 12)$ & $1(-4 ; 6)$ & $1(-3 ; 8)$ & $1(-1 ; 6)$ & $-1(-7 ; 2)$ \\
\hline $\mathrm{Ki} 67^{+}(\%)$ & Not done & Not done & Not done & $3^{A}(0 ; 4)$ & $-1(-1 ; 0)$ & $0(-1 ; 0)$ \\
\hline \multicolumn{7}{|l|}{ B cells } \\
\hline Totall & $-9(-39 ; 130)$ & $33(-37 ; 241)$ & $79(-5 ; 192)$ & $-21(-132 ; 65)$ & $26(-313 ; 66)$ & $55(-109 ; 302)$ \\
\hline Pro-B $(\%)^{\mathrm{J}}$ & $0(0 ; 0)$ & $0(0 ; 0)$ & $0(0 ; 0)$ & $0(0 ; 0)$ & $0(0 ; 0)$ & $0(0 ; 0)$ \\
\hline Activated $(\%)^{\mathrm{K}}$ & $0(-5 ; 2)$ & $8(-4 ; 23)$ & $5(-2 ; 15)$ & $4(-31 ; 10)$ & $16(-10 ; 62)$ & $7(-12 ; 40)$ \\
\hline \multicolumn{7}{|l|}{ Other } \\
\hline NK cellsL & $52(-38 ; 68)$ & $54(-154 ; 122)$ & $12(-310 ; 57)$ & $58^{A}(-156 ; 81)$ & $41^{\mathrm{A}}(15 ; 469)$ & $47(-76 ; 393)$ \\
\hline NKT cells ${ }^{\mathrm{M}}$ & $23(-34 ; 93)$ & $36(12 ; 122)$ & $13(-146 ; 83)$ & $71^{A}(-23 ; 92)$ & $59^{A}(15 ; 469)$ & $65(-4 ; 393)$ \\
\hline
\end{tabular}

dose of rhIL-7, no changes in effector and terminally CD45RA effector subsets were observed. The naive $\mathrm{CD}^{+} \mathrm{T}$ cell population expressing a high level of CD31 antigen was described as recent thymic emigrants (RTEs) and was enriched in T cell receptor excision circle (TREC) content (29). Therefore, we analyzed this population by gating $\mathrm{CD} 31^{\text {hi }}$-expressing $\mathrm{CD} 4^{+} \mathrm{T}$ cells within the naive $\mathrm{CD}_{45 \mathrm{RA}}{ }^{+} \mathrm{CD} 27^{+}$subset. Low and high doses of rhIL-7 therapy led to a significant, but transient, dose-dependent increase of these cell populations at $28 \mathrm{~d}$ (Figure 3 ).

Effects of rhIL-7 on CD8 ${ }^{+} \mathrm{T}$ cell subsets were significantly different from those observed in the $\mathrm{CD}^{+} \mathrm{T}$ cells. Only the high dose of rhIL-7 led to a significant increase in mean absolute counts of naive and central memory cells: from 113 and 209 cells/ $\mu \mathrm{l}$ at baseline to 703 and 592 cells/ $\mu \mathrm{l}$ at $14 \mathrm{~d}$ and 681 and 572 cells/ $\mu \mathrm{l}$ at $28 \mathrm{~d}$ ( $P=0.02$ for all comparisons). These changes were sustained at 12 wk $(P=0.02)$. No effects were noted within the effector memory, effector, and terminally CD45RA ${ }^{+}$effector cells. These results showed that rhIL-7 induces a significant and preferential increase of naive and memory $\mathrm{CD}^{+}$and $\mathrm{CD}^{+} \mathrm{T}$ cells.

Effects of rhIL-7 therapy on cell cycling and immune activation. When rhIL-7 is administered repeatedly, it is critical to investigate the dynamics of IL-7 receptor $\alpha$ chain (IL-7R $\alpha$ ) expression on expanded $\mathrm{T}$ cells. Therefore, we estimated the changes in circulating $\mathrm{T}$ cells that express IL-7R $\alpha$ (CD127) throughout the study. In patients treated with $10 \mu \mathrm{g} / \mathrm{kg}$ rhIL-7, we found a 4 -fold increase of circulating CD4 ${ }^{+}$ and $\mathrm{CD}^{+} \mathrm{T}$ cells that express CD127 at 14 and $28 \mathrm{~d}(P<0.01$ versus baseline for both comparisons) that persisted until $12 \mathrm{wk}$ (2-fold that of baseline, $P=0.002$; Figure 1D). These results indicated that the increase of $\mathrm{T}$ cells is associated with a persistent expression of the receptor. This correlates with previous observations in preclinical models (30) and in cancer patients (31), indicating that rhIL-7 augments $\mathrm{T}$ cell cycling. To evaluate the effects of rhIL-7 in HIVinfected patients, we quantified Ki67 expression in total circulating $\mathrm{CD}^{+}$and $\mathrm{CD}^{+} \mathrm{T}$ cells. At baseline, a median of $1.3 \% \mathrm{CD}^{+} \mathrm{T}$ cells expressed Ki67 in patients from the 2 dose levels. A dose-dependent increase in the frequency of cycling $\mathrm{CD}^{+}$cells was seen within $14 \mathrm{~d}$ of rhIL-7 administration, with approximately $4.1 \%$ of $\mathrm{CD}^{+} \mathrm{T}$ cells expressing Ki67 in subjects treated at the $10-\mu \mathrm{g} / \mathrm{kg}$ dose $(P=0.03$; Figure 4A and Table 2). Analysis of Ki67 expression in different subpopulations of $\mathrm{CD}^{+}$cells showed an increase of cycling cells in all subsets $(P<0.05$ versus baseline) except terminally differentiated effector cells (data not shown). Moreover, the frequency of cycling $\mathrm{CD}^{+}$cells increased significantly in patients treated with the $10-\mu \mathrm{g} /$ $\mathrm{kg}$ dose (Figure 4B and Table 2). After cessation of rhIL-7 therapy, although $\mathrm{CD}^{+}$and $\mathrm{CD}^{+} \mathrm{T}$ cell counts remained higher than baseline values at $28 \mathrm{~d}$ and $12 \mathrm{wk}$, the frequency of cycling $\mathrm{CD}^{+}$and 

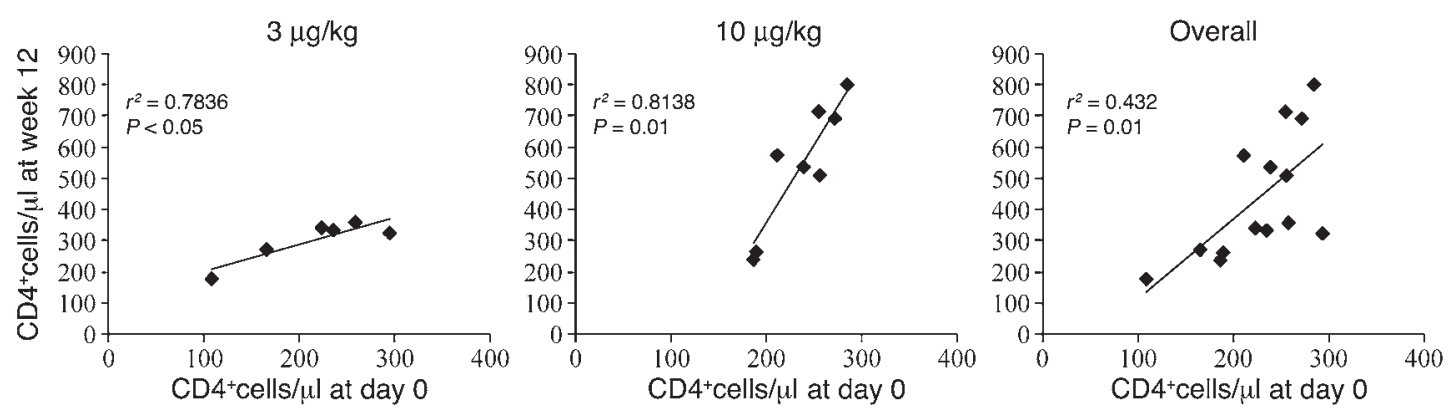

Figure 2

$\mathrm{CD} 4^{+} \mathrm{T}$ cell count prior to rhIL-7 treatment predicts the magnitude of CD4+ $\mathrm{T}$ cell increase after rhlL-7 treatment. The linear correlation between $\mathrm{CD}^{+} \mathrm{T}$ cell count before treatment at $0 \mathrm{~d}$ and $12 \mathrm{wk}$ relative to rhlL-7 treatment initiation at each dose is shown. Overall regression using a Spearman test showed a significant correlation between CD4+ $T$ cell counts at entry CD4+ $T$ cell responses in both groups and in the global population of IL-7-treated patients.

$\mathrm{CD}^{+} \mathrm{T}$ cells declined and returned to baseline levels, which suggests that rhIL-7 might affect T cell survival.

Because residual immune activation persists in HIV-infected patients despite control of viral load under c-ART, it is critical to evaluate the effect of IL-7 on T cell activation markers. At baseline, in patients administered the $10-\mu \mathrm{g} / \mathrm{kg}$ dose, the mean percentage of $\mathrm{CD}^{+}$and $\mathrm{CD}^{+}$cells expressing CD38 and HLA-DR was $3.4 \%$ $(\mathrm{SD}, 1.2 \%)$ and $5 \%(\mathrm{SD}, 2.7 \%)$, respectively. These percentages did not change significantly, either at $14 \mathrm{~d}\left(\mathrm{CD}^{+}, 3.6 \%\right.$; $\left.\mathrm{CD}^{+}, 6.3 \%\right)$ or at $28 \mathrm{~d}\left(\mathrm{CD}^{+}, 3.7 \%\right.$; $\mathrm{CD}^{+}, 6.8 \%$; Figure $4 \mathrm{C}$ and Table 2$)$.

Effects of rhIL-7 therapy on $T$ cell function. In order to determine whether these changes in lymphocyte phenotype were associated
A

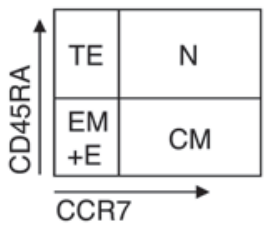

B
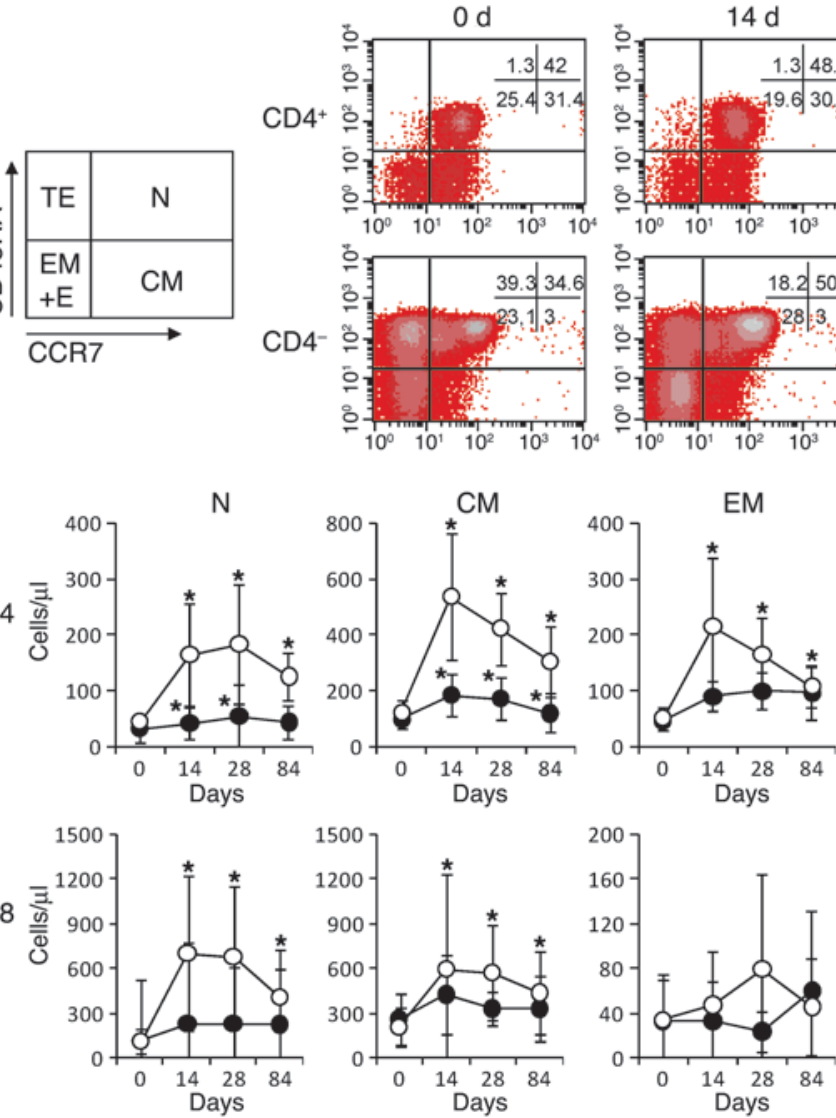

CD4-
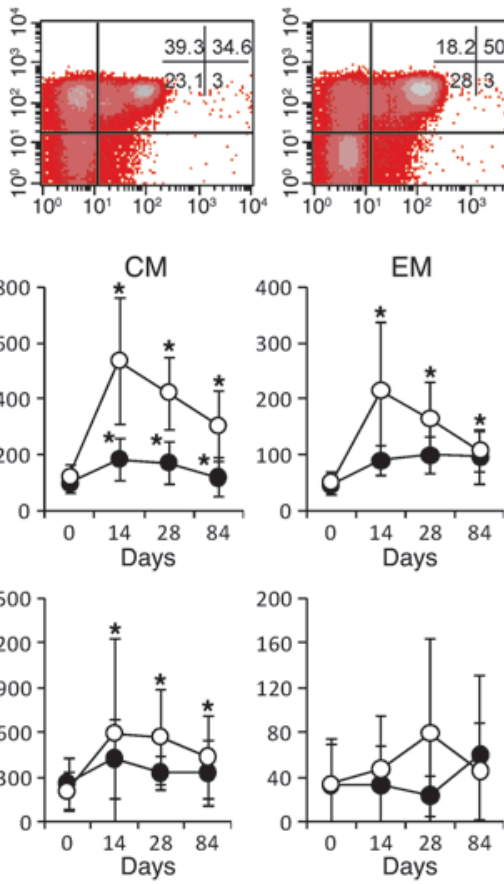
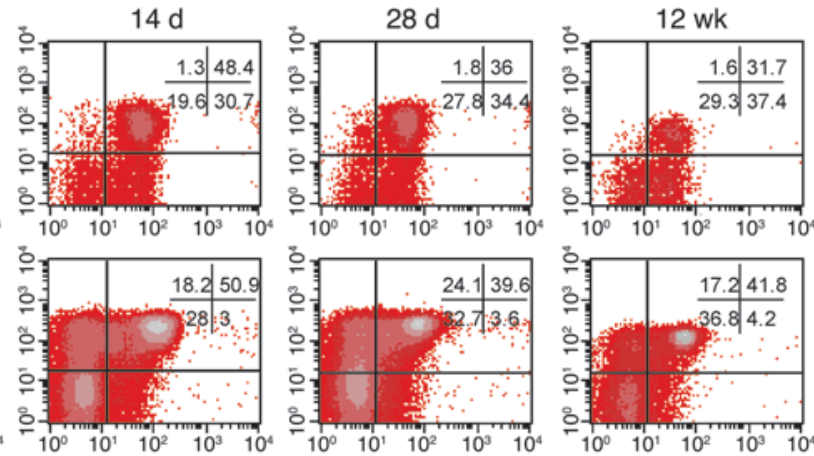

$\mathrm{E}$
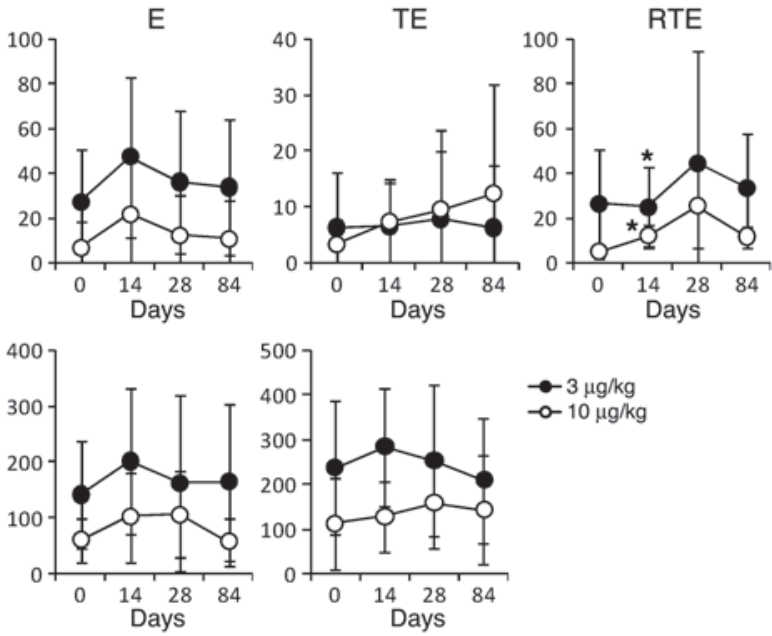

Figure 3

rhIL-7 therapy induces a preferential increase of naive and central memory CD4+ and CD8+ T cells. (A) Representative flow cytometry analysis of $\mathrm{CD}^{+}$and $\mathrm{CD}^{+} \mathrm{T}$ cell populations from a single representative subject treated at the 3- $\mu \mathrm{g} / \mathrm{kg}$ dose. Numbers within the plots indicate the percent of each $T$ cell population: naive $\left(\mathrm{N}\right.$; CD45RA $\left.{ }^{+} \mathrm{CD} 27^{+}\right)$, central memory $\left(\mathrm{CM}\right.$; $\left.\mathrm{CD}^{4} \mathrm{RA}^{-} \mathrm{CD} 27^{+}\right)$, effector memory and effector $(\mathrm{EM}+\mathrm{E}$;

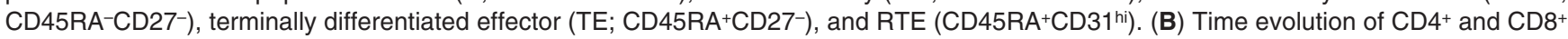
$\mathrm{T}$ cell subsets. Mean $\pm \mathrm{SEM}$ for each cohort is shown. ${ }^{\star} P<0.05$ versus $0 \mathrm{~d}$; Wilcoxon test. 

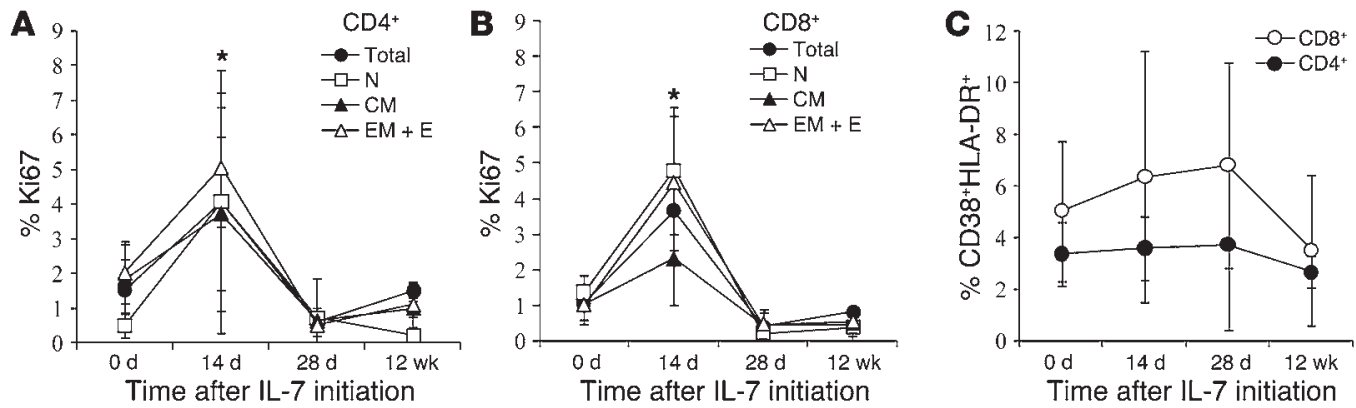

Figure 4

rhlL-7 therapy is not associated with T cell activation, but increases T cell cycling. Analyses were performed in patients treated with the $10-\mu \mathrm{g} / \mathrm{kg}$ dose of rhIL-7. (A and B) Percent cells in $\mathrm{CD}^{+}(\mathbf{A})$ and $\mathrm{CD}^{+}(\mathbf{B}) \mathrm{T}$ cell subpopulations expressing Ki67 via flow cytometry. Mean $\pm \mathrm{SEM}$ for each T cell subset is shown. Ki67 expression significantly increased at $14 \mathrm{~d}$. (C) Percent CD4+ and CD8 ${ }^{+}$activated T cells (HLA-DR ${ }^{+}$CD38 ${ }^{+}$). Error bars denote SD. * $P$ versus 0 d; Wilcoxon test.

with a preserved functional capacity of T cells, we evaluated their capacity to proliferate and to produce cytokines after in vitro stimulation. As shown in Figure 5A, in response to TCR simulation using anti-CD3 antibodies, the proliferative capacity of $\mathrm{T}$ cells from patients in both groups remained unchanged at the different time points. Interestingly, the median frequency of $\mathrm{CD} 4^{+} \mathrm{T}$ cells producing IL-2 after staphylococcal enterotoxin B (SEB) stimulation tended to increase, without reaching statistical significance, from $5.7 \%$ at entry to $8.1 \%$ at $28 \mathrm{~d}$ and $8 \%$ at $12 \mathrm{wk}$, while no significant changes were noted for IFN- $\gamma$-producing $\mathrm{CD}^{+} \mathrm{T}$ cells (Figure 5B). As expected, the frequency of $\mathrm{CD}^{+} \mathrm{T}$ cells producing IL-2 was low in these patients; however, a significant increase was observed, from $0.45 \%$ at entry to $1.5 \%$ at $28 \mathrm{~d}$ and $0.9 \%$ at $12 \mathrm{wk}$ $(P=0.005$, Wilcoxon test; Figure 5B).

Recent studies in a mouse model have shown that IL-7 administration may augment the accumulation of functional viralspecific memory $\mathrm{T}$ cells $(32,33)$. Looking at the data from 7 patients in the $10-\mu \mathrm{g} / \mathrm{kg}$ dose group, we evaluated the functional capacity of $\mathrm{CD}^{+} \mathrm{T}$ cells to produce IL- 2 and IFN- $\gamma$ after stimulation with CMV and HIV antigens in vitro. A significant increase in the median frequency of $\mathrm{CD}^{+} \mathrm{T}$ cells producing IFN- $\gamma$ and/or IL-2 was noted in 4 subjects (Figure 5C). Interestingly, in 3 of these cases, this rise in HIV-specific CD $4^{+} \mathrm{T}$ cells was associated with transient "blips" in HIV replication (see below). Thus, the functional capacity of $\mathrm{T}$ cells in patients treated with IL-7 was at least preserved or remained greater than baseline values. Regarding the dramatic effect of IL-7 on total $\mathrm{CD} 4^{+}$and $\mathrm{CD}^{+} \mathrm{T}$ cell counts, generally these results suggest that admin-

\section{Figure 5}

rhlL-7 expanded T cells respond to polyclonal and antigenic stimulation. PBMCs were collected at the indicated time points, cryopreserved, and then thawed before analysis. (A) Proliferation in response to TCR stimulation (anti-CD3 plus anti-CD28) was measured by $\left[{ }^{3} \mathrm{H}\right]$ incorporation. Similar proliferation levels were observed at each time point. Error bars denote SD. (B) Both CD4 ${ }^{+}$and $C D 8^{+}$T cells produced IFN- $\gamma$ and IL-2 in response to SEB at levels comparable to baseline $28 \mathrm{~d}$ and 12 wk after rhlL-7 therapy. Analyses were performed in patients treated with $10 \mu \mathrm{g} / \mathrm{kg}$ rhIL-7. Error bars denote SD. (C) rhlL-7 therapy increased the capacity of CD4 ${ }^{+} \mathrm{T}$ cells to respond to HIV Gag and CMV antigens by secreting IFN- $\gamma$ and/or IL-2. All 7 patients treated with 10 $\mu \mathrm{g} / \mathrm{kg}$ rhlL-7 were analyzed. istration of IL-7 leads to an increase in the frequency of functional $\mathrm{T}$ cells in these patients.

Safety, tolerability, and pharmacokinetics. IL-7 administration was clinically and biologically well tolerated. Transient local reactions at injection sites were mild or moderate. Constitutional symptoms were infrequent and mild or moderate. With the exception of 1 patient in the $10-\mu \mathrm{g} / \mathrm{kg}$ group, who developed a grade 3 rise
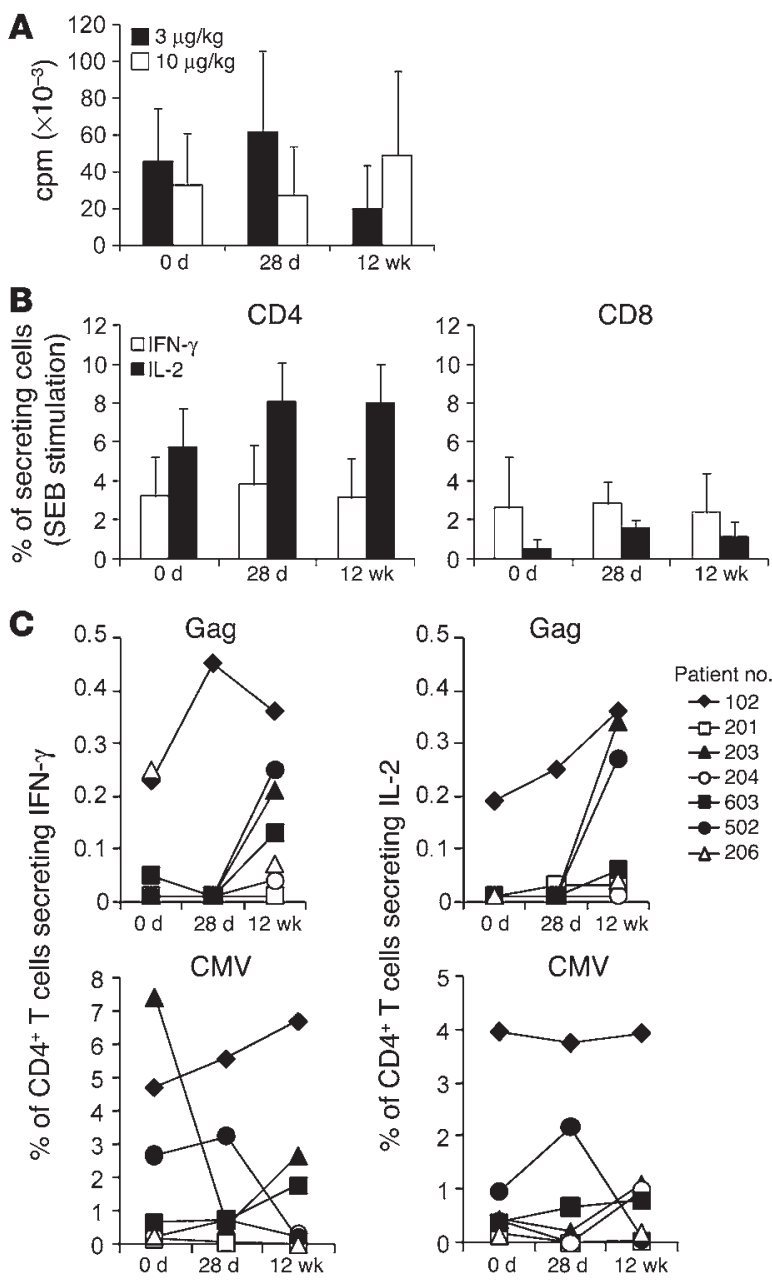


\section{Table 3}

HIV plasma viral load values throughout the study in individual patients

\begin{tabular}{lccccccc} 
Patient no. & $-\mathbf{7 d}$ & $\mathbf{7 d}$ & $\mathbf{1 4} \mathbf{d}$ & $\mathbf{2 1} \mathbf{d}$ & $\mathbf{2 8} \mathbf{d}$ & $\mathbf{9} \mathbf{w k}$ & $\mathbf{1 2} \mathbf{w k}$ \\
$\mathbf{3}-\mu \mathbf{g} / \mathbf{k g}$ dose & & & & & & & \\
401 & - & - & - & - & - & - & - \\
301 & - & - & - & - & - & - & - \\
302 & - & - & - & - & - & - & - \\
101 & - & - & - & - & - & - & - \\
303 & - & - & - & - & - & - & - \\
501 & - & - & - & - & - & - & - \\
$\mathbf{1 0}-\mu \mathrm{g} / \mathrm{kg}$ dose & & & & & & & \\
502 & - & 550 & 180 & 60 & - & - & 120 \\
603 & - & - & 110 & - & - & - & 74 \\
102 & - & 220 & - & - & - & - & - \\
203 & - & - & - & 500 & - & - & 630 \\
201 & - & - & - & - & - & - & - \\
204 & - & - & - & - & - & - & - \\
206 & - & - & - & - & - & - & - \\
\hline
\end{tabular}

Shown are HIV plasma viral load values (copies/ml) for the transient blips of viral replication observed in 4 patients at the $10-\mu \mathrm{g} / \mathrm{kg}$ dose. These patients had detectable HIV Gag-specific CD4+ T cell responses, as assessed via flow cytometry in Figure $5 \mathrm{C}$. All other values $(-)$ were below the 50 copies/ml threshold for plasma HIV-RNA detection.

in liver function enzymes, no grade 3 or 4 clinical or laboratory abnormalities were noted. In the patient with a grade 3 rise in liver function enzymes, liver function testing showed chronic fluctuation above normal values, likely the result of histological metabolic liver steatosis diagnosed 4 years prior to study entry. During the treatment of this patient, levels of alanine aminotransferase (ALT) increased gradually from the 14-d time point, leading to omission of the eighth injection of IL-7. Levels of ALT and aspartate aminotransferase (AST) reached 9.8- and 6.5-fold normal values at $23 \mathrm{~d}$ and returned to baseline values within $20 \mathrm{~d}$ of IL-7 discontinuation. No symptoms, clinical signs, or other laboratory abnormalities were noted. For both patient groups, no significant changes in granulocytes, red blood cells, or platelets were observed throughout the study. Lymphoid organ examination and monitoring of plasma and cellular EBV DNA viral load did not show substantial abnormality (data not shown), providing reassurance regarding the potential risk of lymphoproliferative disorder in this population treated with IL-7. Monitoring of plasma concentration of rhIL-7 showed that maximum plasma concentration values were 101 and $447 \mathrm{pg} / \mathrm{ml}$ after administration with 3 and $10 \mu \mathrm{g} / \mathrm{kg}$ rhIL-7, respectively. Similarly, AUC values correlated well with the dose administered (data not shown), and no neutralizing anti-IL-7 antibodies were detected.

Effects of rbIL-7 therapy on plasma HIV RNA and cellular DNA values. HIV plasma RNA values were monitored throughout the study. No increase of viral load was noted in patients from the $3-\mu \mathrm{g} / \mathrm{kg}$ group (Table 3 ). In contrast, 4 of 8 patients in the $10-\mu \mathrm{g} / \mathrm{kg}$ group experienced a transient elevation of plasma HIV mRNA values. No modifications of antiretroviral regimen or compliance issues with antiretroviral drugs were reported in these patients. Recent in vitro studies have shown that IL-7 may increase HIV infectivity of $\mathrm{CD}^{+} \mathrm{T}$ cells (34-36). With this in mind, we evaluated the cellular content of viral DNA at entry, at $21 \mathrm{~d}$, and at $12 \mathrm{wk}$. We did not find any significant changes in HIV DNA $\log _{10}$ copies per $10^{6}$ PBMCs (Table 4). Since
IL-7 led to a significant increase in $\mathrm{CD}^{+} \mathrm{T}$ cells, it was important to calculate the content of viral DNA per $10^{6} \mathrm{CD} 4^{+} \mathrm{T}$ cells. No significant changes in these values were noted throughout the study. These results show that IL-7 did not directly affect the cellular HIV DNA content, although a possible transient effect on HIV replication could be detected in patients treated with the higher dose.

\section{Discussion}

Although viral load control in HIV-infected patients is an attainable goal with the current potent c-ART regimen, the magnitude of $\mathrm{CD}^{+}$cell restoration among patients remains variable (4-7). Immune restoration is predicted by several imprinted factors, some of which - such as age, genetic background, history of infection, and nadir of $\mathrm{CD} 4^{+}$cells - are beyond the reach of therapeutic intervention (37-43). Nevertheless, the length of time patients spend with low $\mathrm{CD}^{+} \mathrm{T}$ cell counts is clearly associated with a higher morbidity in HIV-infected patients $(9,10,12-14)$. This suggests that a new frontier in HIV therapy may be defined by the maintenance of a high level of $\mathrm{CD}^{+} \mathrm{T}$ cells.

Common $\gamma$ chain cytokines IL-2 and IL-7 play a critical role in $\mathrm{T}$ cell homeostasis and $\mathrm{T}$ cell survival. Both cytokines represent promising immunotherapeutic strategies for the preservation and restoration of the $\mathrm{T}$ cell pool in lymphopenic conditions. Administration of IL-2 cycles leads to a significant and exclusive increase in peripheral CD4 $4^{+} \mathrm{T}$ cell counts in HIV-infected patients (44-47). Although the potential benefit of IL-2 therapy is currently under evaluation in phase III studies, a large set of clinical data shows that its use is limited by a high frequency of acute toxic effects that lead to discontinuation of therapy. Several preclinical studies show that IL-7 administration in mice and primates is safe and has a significant impact on $\mathrm{T}$ cell homeostasis $(25,30,48,49)$. Recently, rhIL-7 administration in cancer patients has provided interesting and encouraging results for its clinical use $(31,50)$. However, IL-7 therapy at supraphysiologic doses in HIV-infected individuals initially raised several specific issues surrounding the complex mechanisms of T cell depletion associated with HIV infection and the potential risk of viral replication $(35,51)$. To address these questions regarding rhIL-7 administration in HIV-infected patients, we conducted a prospective multicenter study. We demonstrate herein that repeated administration of rhIL-7 was safely associated with robust and sustained increases in circulating $\mathrm{CD}^{+}$and $\mathrm{CD} 8^{+}$lymphocytes in chronically HIV-infected patients with persistently low $\mathrm{CD} 4^{+} \mathrm{T}$ cell counts despite virologic suppression under c-ART. These effects were clearly dose dependent and already significant at lower doses. We showed that expanded $\mathrm{CD}^{+}$and $\mathrm{CD} 8^{+} \mathrm{T}$ cells remained functional and responded in vitro to TCR stimulation and produced intracellular cytokines after polyclonal and antigen-specific stimulation. Interestingly enough, in the context of HIV chronic lympho-

\section{Table 4}

Changes in viral load in PBMC and CD4+ cell populations

\begin{tabular}{|c|c|c|c|c|}
\hline \multirow[b]{2}{*}{ Cell population } & \multicolumn{2}{|c|}{$3-\mu \mathrm{g} / \mathrm{kg}$ dose } & \multicolumn{2}{|c|}{$10-\mu \mathrm{g} / \mathrm{kg}$ dose } \\
\hline & $21 d$ & 12 wk & $21 d$ & 12 wk \\
\hline PBMCs & +0.2 & +0.2 & +0.2 & +0.2 \\
\hline CD4+ cells & +0.0 & +0.2 & +0.0 & -0.1 \\
\hline
\end{tabular}

Values denote median change relative to baseline in HIV-1 DNA proviral load ( $\log _{10}$ copies per $10^{6}$ cells of the indicated population). 
penic $\mathrm{T}$ cell depletion, increases in $\mathrm{CD}^{+}$cells remained significant more than $45 \mathrm{wk}$ after cessation of IL-7 administration.

Naive and memory T cells are both dependent on IL-7 for survival and homeostatic regulation in lymphopenic conditions (52, 53). In the setting of HIV infection, the dynamics of $\mathrm{CD}^{+}$and $\mathrm{CD}^{+} \mathrm{T}$ cell subsets are severely perturbed. Several factors influence these defects, including the level of virus replication, imbalance of cytokine production, dysregulation of cytokine receptor expression, and chronic immune activation (18). A high proportion of HIV-specific CD8 ${ }^{+}$cells also loses expression of IL-7R $\alpha$ and exhibits an activated memory phenotype $(54,55)$. During HIV infection, as in other lymphopenic conditions, IL-7 plasma levels are increased (56-58) and correlate with sustained downregulation of IL-7R $\alpha$ on naive and memory T cells (59). Whether circulating levels of IL-7 explain the downregulation of CD127 expression on $\mathrm{T}$ cells remains unclear, since the ligand-binding receptor usually results in a transient downmodulation of the cytokine receptor. A more likely explanation is that downmodulation of CD127 expression represents a state of cell differentiation driven by HIVmediated chronic immune activation. More recently, a relative expansion of $\mathrm{CD}^{+} \mathrm{CD} 127^{-} \mathrm{CD} 25^{-} \mathrm{T}$ cells exhibiting features of activated effector cells has been reported in HIV-infected subjects (60). Expansion of these cells may be driven by chronic immune activation and have detrimental effects of the homeostasis of naive and central memory $T$ cells in the periphery. Interestingly, we found that IL-7 therapy led to a significant increase of naive and central memory $\mathrm{CD} 4^{+}$and $\mathrm{CD}^{+} \mathrm{T}$ cell populations that are usually functionally impaired and prone to $\mathrm{T}$ cell exhaustion in HIV infection. Regarding the expected expansion of terminally differentiated effector cells observed in HIV infection $(61,62)$, generally our results showed that IL-7 therapy may reshape the balance of $\mathrm{T}$ cell subsets in favor of naive and central memory $\mathrm{T}$ cells in HIV-infected subjects.

The mechanisms of T cell expansion during IL-7 therapy may involve $\mathrm{T}$ cell cycling, increased thymic output, and T cell survival. Whether the thymic output contributes to the reconstitution of the T cell pool in IL-7-treated HIV patients is not easy to assess. In patients treated with $10-\mu \mathrm{g} / \mathrm{kg}$ rhIL-7, precise analysis of the earliest subset of naive $\mathrm{CD} 4^{+} \mathrm{T}$ cells showed a significant increase in naive $\mathrm{CD}^{+} \mathrm{T}$ cells expressing a high density of the CD31 antigen $\left(\mathrm{CD} 4^{+} \mathrm{CD} 45 \mathrm{RA}^{+} \mathrm{CD} 27^{+} \mathrm{CD} 31^{\text {hi }}\right)$, a marker recently used to identify RTEs (29). This result might suggest an effect of IL-7 on thymic output. However, we were unable to confirm this effect, because the low number of these cells did not allow us to analyze their TREC content, which would have provided an indirect measure of thymic output (63). Nevertheless, analysis of sorted RTEs in cancer patients treated with IL-7 showed a dilution of TREC content related to the high level of cycling cells in this subset (31). The same result would be expected in our study, given the high level of $\mathrm{Ki}^{2} 7^{+}$cells within the naive $\mathrm{CD}^{+}$and $\mathrm{CD}^{+} \mathrm{T}$ cell subsets (Figure 4). On the other hand, the contribution of increased thymic output to the changes in naive $\mathrm{CD}^{+} \mathrm{T}$ cell expansion could be delayed for months and requires further evaluation in patients receiving chronic IL-7 therapy. As assessed by Ki67 staining, rhIL-7 therapy induced a peak of cell proliferation in the different populations of $\mathrm{CD}^{+}$and $\mathrm{CD}^{+} \mathrm{T}$ cells. It is noteworthy that this effect was not associated with increased expression of activation markers on $\mathrm{CD}^{+} \mathrm{T}$ cells. The same experiments performed 2 or $10 \mathrm{wk}$ after cessation of IL-7 administration showed that the level of $\mathrm{T}$ cell cycling returned to baseline in all patients. At the same time points, the majority of patients maintained a level of CD4 ${ }^{+} \mathrm{T}$ cells significantly higher than that at baseline. Together, these data suggest that IL-7 expanded T cells may result from 2 phases: a first phase related to a rise in $\mathrm{CD}^{+} \mathrm{T}$ cells caused by an acute effect on cell proliferation, and a second phase raising the possibility of a preferential effect on $T$ cell survival.

From a clinical standpoint, one concern is a possible refractory response to repeated administrations of rhIL-7 related to the downmodulation of IL-7R $\alpha$ on expanded cells. Although the schedule of administration of IL-7 in our study and in cancer patients seems empirical, administration every other day was based upon data in primate models showing that IL-7 induced transient downmodulation of its receptor on peripheral T cells (48). We did not check for the kinetics of IL-7R $\alpha$ expression immediately following IL-7 administration. However, in the long-term follow-up, we found that rhIL-7-expanded T cells continuously expressed IL-7R $\alpha$. Moreover, although not glycosylated, rhIL-7 did not elicit neutralizing antibodies, and no patient had experienced lymphopenia after 1 year of follow-up. The population of patients selected in this study failed to restore $\mathrm{CD} 4^{+} \mathrm{T}$ cell counts despite a lengthy period of c-ART and prolonged suppression of viral replication. Our results showed that this population should benefit most from IL-7 therapy, since tolerated doses caused significantly increased $\mathrm{CD} 4^{+} \mathrm{T}$ cell counts. On the other hand, correlation between baseline $\mathrm{CD}^{+}$cell counts and the CD4 response to IL-7 suggests that the population selected may be the group that responds less to IL-7. Therefore, when considering the future of IL-7 studies, lower doses should still continue to be evaluated, because a stronger effect of IL-7 at lower doses could be expected in less immunocompromised patients. One clinical consequence of these observations is that IL-7 might represent a promising cytokine for treatment of chronic lymphopenic conditions such as HIV disease, where sustained therapy is required over many years.

One possible limitation of the use of IL-7 in HIV settings was raised by experimental data showing that IL-7 may enhance HIV replication $(35,36)$. In addition, IL-7 induces a state of virus permissiveness in quiescent or naive $\mathrm{CD}^{+} \mathrm{T}$ cells (64). Finally, in vitro, IL-7 powerfully stimulates transcription and replication of quiescent HIV provirus integrated in mononuclear cells from patients $(51,65)$. This effect appeared to be more potent and qualitatively different than that with IL-2, since quasispecies reactivated by both cytokines were widely distinct (51). In our study, patients treated at the $3-\mu \mathrm{g} / \mathrm{kg}$ dose did not experience any blips in viral replication. In contrast, 4 of 7 patients treated with the $10-\mu \mathrm{g} / \mathrm{kg}$ dose had transient and limited peaks of viral replication within the period of IL-7 administration or at $12 \mathrm{wk}$. The explanation for these blips is unclear, because we did not find any obvious clinical (lack of therapy adherence, drug interaction, changes in drug regimen, or intercurrent infection) or immunological (markers of cell activation) explanation. However, we found that IL-7 did not affect the pool of CD4 ${ }^{+}$ infected cells, as assessed by the constant values of HIV DNA content in PBMCs or $\mathrm{CD}^{+}{ }^{+} \mathrm{T}$ cells throughout the study. Final interpretation of the effects of IL-7 in vivo on viral replication is limited by the absence of a control group in our study. Nevertheless, these results underscore the importance of carefully monitoring viral load in future randomized studies. It is also interesting to note that all 4 patients with transient viral replication exhibited a significant rise in the frequency of IL-2/IFN- $\gamma$ HIV-Gag-specific CD $4^{+} \mathrm{T}$ cell responses. This observation might have immunological and clinical consequences for the future development of rhIL-7 in immu- 
nocompromised patients. First, it demonstrates that expanded $\mathrm{CD}^{+} \mathrm{T}$ cells under rhIL-7 therapy are functional and capable of responding to TCR stimulation. Second, it suggests that the capacity of rhIL-7 to stimulate responses to transient and weak antigenic challenges may be a rationale for the clinical use of this cytokine as a powerful immunotherapeutic agent to boost vaccine-induced T cell memory (32). Thus, this potential effect of rhIL-7 therapy on viral replication may represent both a concern and an opportunity for the use of IL-7 as an agent that may mobilize latent reservoirs and $\mathrm{T}$ cell memory anamnestic responses, like those recently demonstrated in murine models of chronic viral infection (33).

Broadly viewed, this clinical study - which we believe to be the first - of repeated IL-7 administration in chronically lymphopenic HIV-infected patients presents evidence that rhIL-7 therapy is better tolerated compared with other immunotherapeutic strategies. The effects of IL-7 on naive and memory subpopulations could restore a homeostatic equilibrium not achieved by the control of viral load alone under c-ART. This reshaping of the immune system is associated with conserved functional properties of T cells and a low level of immune activation. Moreover, the pharmacokinetic properties of IL-7 offer the possibility of an intermittent therapy as an adjunct to ongoing c-ART. The next generation of glycosylated IL-7, characterized by a longer half-life and better in vivo stability compared with the E. coli-produced molecule used in the present study, should permit the development of an optimized therapeutic strategy with less frequent injections of IL-7, thus providing a more convenient schedule for administration in patients. Furthermore, the good profile of glycosylation should lead to less immunogenicity and allow for additional cycles of treatment. These properties may confer a clinical benefit that should be demonstrated in future large-scale randomized clinical studies.

\section{Methods}

Patients. Eligible patients were HIV-1-infected adults who had a CD4+ cell count of 100-400 cells/ $\mu \mathrm{l}$ and plasma HIV RNA levels less than 50 copies/ $\mathrm{ml}$ for at least $6 \mathrm{mo}$ and had received c-ART for at least $12 \mathrm{mo}$. The population of patients selected in this study failed to restore $\mathrm{CD} 4^{+} \mathrm{T}$ cell counts despite a lengthy period of c-ART and prolonged suppression of viral replication. Major exclusion criteria were: a history of autoimmune disease; any malignancy; coinfection with hepatitis B or C virus; pregnancy; and concomitant or previous treatment with IFN, other cytokines, anti-HIV vaccines, steroids, or any other immunomodulators. Blood cells and serum chemistry values of patients were required to be within acceptable ranges.

$I L-7$. The drug substance CYT 99007 is a nonglycosylated 153-aa protein expressed as inclusion bodies in a recombined strain of $E$. coli containing the DNA that encodes for the human protein (sequence originating from the gene cloned from a human hepatocarcinoma). The product used in this phase I clinical trial was GMP manufactured at a 50-1 fermentation scale. After fermentation, the culture was harvested, and a series of chromatographic steps was performed to extract and purify the drug substance.

The purity of the drug substance was $100 \%$ by size-exclusion HPLC and greater than $98.5 \%$ by SDS-PAGE. The product was lyophilized in a buffer with $10 \mathrm{mM}$ L-glutamic acid and $5 \mathrm{~g}$ sucrose per $1 \mathrm{~g}$ CYT 99007 protein and then reconstituted in sterile water. After reconstitution, the concentration of CYT 99007 was $1 \mathrm{mg} / \mathrm{ml}$, pH 5.0. All patients were treated with CYT 99007 (batch no. M-ILK-PO2-FOR/2; provided by Cytheris S.A.), supplied as freeze-dried powder suitable for s.c. injection after reconstitution with bacteriostatic water.

Study design and endpoints. Patients were enrolled in a standard, multicenter, prospective, open-label, interpatient, dose-escalating phase I/IIa study of rhIL-7 therapy. The protocol was approved by the Ethics Committee of Henri Mondor Hospital (Creteil, France) and registered in the EudraCT database (http://eudract.emea.europa.eu/; protocol no. 2004003772-11A). All subjects provided written informed consent before enrollment. Visits for safety and immunological efficacy were performed at $7,14,21,28$, and $35 \mathrm{~d}$ and at 9 and $12 \mathrm{wk}$. At each visit, clinical data were collected through an interim medical history and physical examination including lymphoid organs, and blood specimens were obtained. Routine analyses were performed at each site throughout the follow-up period and included complete blood and lymphocyte counts and tests of liver, kidney, and pancreatic function. Measurement of plasma HIV-1 mRNA, with a lower limit of detection of 50 copies $/ \mathrm{ml}$, and of cellular HIV-1 DNA (66) were performed centrally at Hôpital Necker-EnfantsMalades. Blood samples were also regularly collected for pharmacokinetics and immunogenicity assessment. Safety was assessed through the reporting of adverse events and laboratory abnormalities, the severity of which was assessed with use of the ANRS toxicity grading scale (67). The primary endpoint of this study was safety. Safety endpoints included the proportion of patients with grade 3-4 adverse events and laboratory abnormalities. Virological safety of rhIL-7 administration was part of the safety criteria, and dose-limiting toxicity was defined as an increase of HIV plasma RNA greater than 500 copies/ $\mathrm{ml}$ at 2 consecutive evaluations $2 \mathrm{wk}$ apart. Immunogenicity of rhIL-7 was also part of the safety criteria, and dose-limiting toxicity was defined as a detection of anti-IL-7 neutralizing antibody with a 1:400 or greater titer. An Independent Adverse Event Review Expert monitored safety and efficacy data throughout the study. Secondary outcomes included changes from baseline in $\mathrm{CD}^{+}$and $\mathrm{CD}^{+}$ $\mathrm{T}$ cell counts. Immunological responses were defined as a $50 \%$ increase in $\mathrm{CD} 4{ }^{+} \mathrm{T}$ cells counts between baseline and the mean of the 2 values measured at 21 and $28 \mathrm{~d}$, the final evaluation of this study. At $12 \mathrm{wk}$, patients were asked to enroll in a long-term follow-up until $48 \mathrm{wk}$ in order to determine long-term safety and the residual $\mathrm{CD}^{+}$cell increase until the end of the first year. During this period, c-ART was unchanged, and patients did not receive any injections of IL-7.

Flow cytometry. We used flow cytometry to assess the intracellular and surface expression of specific markers on PBMCs collected at specified time points. Analyses were performed on EDTA anticoagulated peripheral blood specimens on the same day without cryopreservation in a centralized laboratory. Samples were stained for 4-color flow cytometry using a whole-blood lysis method and analyzed on a FACSCalibur cytometer (BD Biosciences) using CellQuest software (version 3.3; BD Biosciences). $\mathrm{T}$ cells and $\mathrm{T}$ cell subpopulations were characterized using a combination of directly conjugated monoclonal antibodies: anti-CD3, anti-CD4, anti-CD8, anti- $\alpha / \beta$ TCR, and anti- $\gamma / \delta$ TCR. NK and NKT cell populations were characterized using a combination of anti-CD16 and anti-CD56 antibodies evaluated on $\mathrm{CD}^{-}$and $\mathrm{CD}^{+}$lymphocytes, respectively. We identified pro- $\mathrm{B}$ cells as $\mathrm{CD} 34^{+} \mathrm{CD} 19^{+}$, mature $\mathrm{B}$ cells as $\mathrm{CD} 19^{+} \mathrm{CD} 20^{+}$, and activated $\mathrm{B}$ cells as $\mathrm{CD} 19^{+} \mathrm{CD} 10^{+}$. We further analyzed $T$ cell subsets on fresh PBMCs using anti-CD27, anti-CD28, and antiCD45RA antibodies and defined by the following antibody expression patterns: naive $\mathrm{CD} 4^{+}$and $\mathrm{CD} 8^{+}, \mathrm{CD} 27^{+} \mathrm{CD} 28^{+} \mathrm{CD} 45 \mathrm{RA}^{+}$; central memory $\mathrm{CD}^{+}$and $\mathrm{CD}^{+}, \mathrm{CD} 27^{+} \mathrm{CD} 28^{+} \mathrm{CD} 45 \mathrm{RA}^{-}$; effector memory $\mathrm{CD}^{+}, \mathrm{CD}^{2} 7^{-}$ $\mathrm{CD}^{2} 8^{+} \mathrm{CD} 45 \mathrm{RA}^{-}$; effector memory $\mathrm{CD}^{+}, \mathrm{CD}^{2} 7^{+} \mathrm{CD} 28^{-} \mathrm{CD} 45 \mathrm{RA}{ }^{-}$; effector $\mathrm{CD}^{+}$and $\mathrm{CD}^{+}, \mathrm{CD} 27^{-} \mathrm{CD} 28^{-} \mathrm{CD} 45 \mathrm{RA}^{-}$; terminally differentiated effector $\mathrm{CD}^{+}$and $\mathrm{CD}^{+}, \mathrm{CD} 27^{-} \mathrm{CD} 28^{-} \mathrm{CD} 45 \mathrm{RA}^{+}$. RTEs were characterized as $\mathrm{CD} 4{ }^{+} \mathrm{CD} 45 \mathrm{RA}^{+} \mathrm{CD} 27^{+} \mathrm{CD} 31^{\text {hi }}$ cells. We used $5 \mathrm{ml}$ blood to generate mononuclear cells via a density gradient separation for determination of intracellular Ki67 expression in T cells. Cells were stained with antiCD3, anti-CD4, or anti-CD8; fixed; permeabilized (BD Biosciences); and stained for intracellular markers with isotype control or Ki67. Expression 
of Ki67 was determined in $\mathrm{T}$ cell subsets following gating on $\mathrm{CD} 3^{+} \mathrm{CD} 4^{+}$ or $\mathrm{CD}^{+} \mathrm{CD}^{+} \mathrm{T}$ cell populations. Expression of activation markers was evaluated using anti-CD38 and HLA-DR antibodies. Expression of IL-7R $\alpha$ was evaluated using anti-CD127 antibodies. We used directly conjugated mouse IgG isotype controls to ascertain background staining. All antibodies were obtained from BD Biosciences. The absolute numbers for each population were generated using absolute peripheral blood lymphocyte counts. We calculated the absolute number of cells/ml expressing a specific phenotype by multiplying the proportion of the subset by the absolute number of $\mathrm{CD}^{+}$or $\mathrm{CD}^{+} \mathrm{T}$ cells.

Proliferation assay. Freshly isolated PBMCs were added in round-bottomed microtiter plates at $10^{6}$ cells $/ \mathrm{ml}$ in $100 \mu$ RPMI 1640 medium supplemented with $10 \%$ human $\mathrm{AB}$ serum. The cells were then treated in triplicate with 100 $\mu \mathrm{l}$ medium containing $2 \mu \mathrm{g} / \mathrm{ml}$ of baculovirus-derived recombinant p24 Gag protein (Protein Science), purified protein derivative (PPD; Staten Serum Institute), or CMV antigen (Virion). Positive controls consisted of cells incubated with $5 \mu \mathrm{g} / \mathrm{ml}$ each of purified monoclonal CD3 (Clone UCHT1; Beckman Coulter) and CD28 (Clone CD28.2; Beckman Coulter) antibodies; negative controls consisted of cells incubated with medium alone. On day 4, each well was pulsed with $0.5 \mu \mathrm{Ci}\left[{ }^{3} \mathrm{H}\right]$ thymidine (Amersham Pharmacia). Data are reported as net cpm, calculated as mean $\mathrm{cpm}\left[{ }^{3} \mathrm{H}\right]$ thymidine incorporation of cells stimulated with antigen less the mean cpm of unstimulated cells.

Intracellular cytokine staining assay. PBMCs $\left(2 \times 10^{6}\right.$ cells) were incubated in $500 \mu \mathrm{l}$ RPMI 1640 medium supplemented with $10 \%$ human AB serum and $1 \mu \mathrm{g} / \mathrm{ml}$ each of anti-CD28 and anti-CD49d antibodies and stimulated overnight with $5 \mu \mathrm{g} / \mathrm{ml}$ of either baculovirus-derived recombinant p24 Gag protein (Protein Science) or CMV antigen (Virion). Brefeldin A $(5 \mu \mathrm{g} / \mathrm{ml}$; Sigma-Aldrich) was added after the first $2 \mathrm{~h}$. Positive and negative controls consisted of cells incubated with and without $5 \mu \mathrm{g} / \mathrm{ml} \mathrm{SEB}$ (Sigma-Aldrich), respectively. Following stimulation, cells were stained for surface antigen with peridin chlorophyll-conjugated CD4 and allophycocyanin-conjugated CD69 antibodies (BD Biosciences). Cells were fixed and permeabilized (FACS Permeabilizing Solution; BD Biosciences) and stained for intracellular cytokines using FITC-conjugated IFN- $\gamma$ and PEconjugated IL-2 antibodies from BD Biosciences. Fluorescence was measured on a 4-color flow cytometer (FACSCalibur; BD Biosciences) using CellQuest software (version 3.3; BD Biosciences). A minimum of 30,000 $\mathrm{CD}^{+}$gated events was acquired. The percentage of cytokine-producing $\mathrm{CD}^{+}$and $\mathrm{CD}^{-}$- cells was determined after subtracting the percentage of cytokine-producing cells in negative controls.

Pharmacokinetic analysis. Plasma IL-7 levels were measured at baseline; at $1,2,4,6$, and $48 \mathrm{~h}$ after the first injection of rhIL-7; at 11 and $16 \mathrm{~d}$ prior to administration; and $48 \mathrm{~h}$ after the last administration. Levels were assayed by ELISA (Diaclone SAS), with a lower limit of detection established at $3.125 \mathrm{pg} / \mathrm{ml}$. The CYT 99007 pharmacokinetic profile and main parameters were calculated using the noncompartmental extravascular model of Kinetica software (version 4.2; Thermo Scientific).

Immunogenicity analyses. Anti-IL-7 antibodies were measured at baseline, $28 \mathrm{~d}, 35 \mathrm{~d}$, and $12 \mathrm{wk}$ using an IL-7-specific ELISA test developed by Cytheris and transferred to SPI-bio. The neutralizing capacity of anti-IL-7 antibodies detected at $28 \mathrm{~d}$ was assayed by bioassay.

Statistics. All patients who received at least 1 injection of rhIL-7 were included in the safety analysis, while immunological activity was evaluated in patients who received more than 1 injection. The Freeman test was used to analyze changes in $\mathrm{CD}^{+}$or $\mathrm{CD} 8^{+}$cell counts throughout the study. Differences in continuous variables were analyzed by using the nonparametric Wilcoxon rank-sum test for paired data. Statistical analysis was performed with SAS software (version 9.1; SAS Institute Inc). A $P$ value less than 0.05 was considered significant.

Note added in proof. Recent results of the large phase III SILCAAT and ESPRIT trials have shown that addition of IL-2 to c-ART does not provide any additional clinical benefit in HIV-infected patients $(68,69)$.

\section{Acknowledgments}

The authors acknowledge the subjects who participated in this study. We also thank C. Orefice, C. Abdelkrim, and R. Buffet for clinical and logistic support; H. Kared, B. Fief, and S. Delluc for technical support for immunological substudies; and C. Bazin for chairing the Adverse Event Review Committee.

Received for publication November 14, 2008, and accepted in revised form January 28, 2009.

Address correspondence to: Yves Levy, Service d'immunologie clinique and INSERM Unit U841, Hôpital Henri Mondor 51, avenue du Maréchal de Lattre de Tassigny, Cedex, 94010 Creteil, France. Phone 33-149-81-24-55; Fax: 33-149-81-24-69; E-mail: yves.levy@ hmn.aphp.fr.

This work was presented in part at the 14th Conference of Retroviruses and Opportunistic Infections in Los Angeles, California, USA, on February 25-28, 2007, and at the 15th Conference of Retroviruses and Opportunistic Infections in Boston, Massachusetts, USA, on February 3-6, 2008.
1. Hammer, S.M., et al. 1997. A controlled trial of two nucleoside analogues plus indinavir in persons with human immunodeficiency virus infection and CD 4 cell counts of 200 per cubic millimeter or less. AIDS Clinical Trials Group 320 Study Team. N. Engl. J. Med. 337:725-733.

2. Mocroft, A., et al. 1998. Changing patterns of mortality across Europe in patients infected with HIV-1. EuroSIDA Study Group. Lancet. 352:1725-1730.

3. Palella, F.J., Jr., et al. 1998. Declining morbidity and mortality among patients with advanced human immunodeficiency virus infection. HIV Outpatient Study Investigators. N. Engl. J. Med. 338:853-860.

4. Grabar, S., et al. 2000. Clinical outcome of patients with HIV-1 infection according to immunologic and virologic response after 6 months of highly active antiretroviral therapy. Ann. Intern. Med. 133:401-410.

5. Moore, D.M., et al. 2006. Regimen-dependent variations in adherence to therapy and virological suppression in patients initiating protease inhibi- tor-based highly active antiretroviral therapy. HIV Med. 7:311-316.

6. Gras, L., et al. 2007. CD4 cell counts of 800 cells/ $\mathrm{mm} 3$ or greater after 7 years of highly active antiretroviral therapy are feasible in most patients starting with 350 cells $/ \mathrm{mm} 3$ or greater. J. Acquir. Immune Defic. Syndr. 45:183-192.

7. Rodriguez, B., et al. 2006. Predictive value of plasma HIV RNA level on rate of CD4 T-cell decline in untreated HIV infection. JAMA. 296:1498-1506.

8. Antiretroviral Therapy Cohort Collaboration. 2008. Life expectancy of individuals on combination antiretroviral therapy in high-income countries: a collaborative analysis of 14 cohort studies. Lancet. 372:293-299.

9. Smit, C., et al. 2006. Effective therapy has altered the spectrum of cause-specific mortality following HIV seroconversion. AIDS. 20:741-749.

10. Weber, R., et al. 2006. Liver-related deaths in persons infected with the human immunodeficiency virus: the D:A:D study. Arch. Intern. Med. 166:1632-1641.
11. Lewden, C., et al. 2008. Changes in causes of death among adults infected by HIV between 2000 and 2005: The "Mortalite 2000 and 2005" surveys (ANRS EN19 and Mortavic). J. Acquir. Immune Defic. Syndr. 48:590-598.

12. El-Sadr, W.M., et al. 2006. CD4+ count-guided interruption of antiretroviral treatment. N. Engl. J. Med. 355:2283-2296.

13. Baker, J.V., et al. 2008. Poor initial CD4+ recovery with antiretroviral therapy prolongs immune depletion and increases risk for AIDS and non-AIDS diseases. J. Acquir. Immune Defic. Syndr. 48:541-546.

14. Baker, J.V., et al. 2008. CD4+ count and risk of nonAIDS diseases following initial treatment for HIV infection. AIDS. 22:841-848.

15. Hazenberg, M.D., et al. 2003. Persistent immune activation in HIV-1 infection is associated with progression to AIDS. AIDS. 17:1881-1888.

16. Hunt, P.W., et al. 2003. T cell activation is associated with lower CD4+ T cell gains in human immunodeficiency virus-infected patients with sustained 
viral suppression during antiretroviral therapy. J. Infect. Dis. 187:1534-1543.

17. Jameson, S.C. 2002. Maintaining the norm: T-cell homeostasis. Nat. Rev. Immunol. 2:547-556.

18. Douek, D.C., Picker, L.J., and Koup, R.A. 2003. T cell dynamics in HIV-1 infection. Annu. Rev. Immu nol. 21:265-304.

19. Fry, T.J., et al. 2001. A potential role for interleukin-7 in T-cell homeostasis. Blood. 97:2983-2990.

20. Grabstein, K.H., et al. 1993. Inhibition of murine B and Tlymphopoiesis in vivo by an anti-interleukin 7 monoclonal antibody. J. Exp. Med. 178:257-264.

21. Murray, R., Suda, T., Wrighton, N., Lee, F., and Zlotnik, A. 1989. IL-7 is a growth and maintenance factor for mature and immature thymocyte subsets. Int. Immunol. 1:526-531.

22. Puel, A., Ziegler, S.F., Buckley, R.H., and Leonard, W.J. 1998. Defective IL7R expression in $\mathrm{T}(-) \mathrm{B}(+) \mathrm{NK}(+)$ severe combined immunodeficiency. Nat. Genet. 20:394-397.

23. von Freeden-Jeffry, U., et al. 1995. Lymphopenia in interleukin (IL)-7 gene-deleted mice identifies IL-7 as a nonredundant cytokine. J. Exp. Med. 181:1519-1526.

24. Schluns, K.S., Kieper, W.C., Jameson, S.C., and Lefrancois, L. 2000. Interleukin-7 mediates the homeostasis of naive and memory CD8 T cells in vivo. Nat. Immunol. 1:426-432.

25. Mackall, C.L., et al. 2001. IL-7 increases both thymic-dependent and thymic-independent T-cell regeneration after bone marrow transplantation. Blood. 97:1491-1497.

26. Vassena, L., Proschan, M., Fauci, A.S., and Lusso, P. 2007. Interleukin 7 reduces the levels of spontaneous apoptosis in CD4+ and CD8+ T cells from HIV-1-infected individuals. Proc. Natl. Acad. Sci. U. S. A. 104:2355-2360.

27. Lelievre, J., Berry, A., and Benoit-Vical, F. 2007. Artemisinin and chloroquine: do mode of action and mechanism of resistance involve the same protagonists? Curr. Opin. Investig. Drugs. 8:117-124.

28. Malaspina, A., et al. 2006. Appearance of immature/transitional B cells in HIV-infected individuals with advanced disease: correlation with increased IL-7. Proc. Natl. Acad. Sci. U. S. A. 103:2262-2267.

29. Kimmig, S., et al. 2002. Two subsets of naive Thelper cells with distinct $\mathrm{T}$ cell receptor excision circle content in human adult peripheral blood. J. Exp. Med. 195:789-794.

30. Fry, T.J., et al. 2003. IL-7 therapy dramatically alters peripheral T-cell homeostasis in normal and SIVinfected nonhuman primates. Blood. 101:2294-2299.

31. Sportes, C., et al. 2008. Administration of rhIL-7 in humans increases in vivo TCR repertoire diversity by preferential expansion of naive $\mathrm{T}$ cell subsets. J. Exp. Med. 205:1701-1714.

32. Purton, J.F., Martin, C.E., and Surh, C.D. 2008 Enhancing T cell memory: IL-7 as an adjuvant to boost memory T-cell generation. Immunol. Cell Biol. 86:385-386

33. Nanjappa, S.G., Walent, J.H., Morre, M., and Suresh, M. 2008. Effects of IL-7 on memory CD8 $\mathrm{T}$ cell homeostasis are influenced by the timing of therapy in mice. J. Clin. Invest. 118:1027-1039.

34. Schmitt, N., et al. 2003. Positive regulation of CXCR4 expression and signaling by interleukin-7 in CD4+ mature thymocytes correlates with their capacity to favor human immunodeficiency X4 virus replication. J. Virol. 77:5784-5793.

35. Smithgall, M.D., Wong, J.G., Critchett, K.E., and Haffar, O.K. 1996. IL-7 up-regulates HIV-1 replication in naturally infected peripheral blood mono- nuclear cells. J. Immunol. 156:2324-2330.

36. Chene, L., et al. 1999. Thymocyte-thymic epithelial cell interaction leads to high-level replication of human immunodeficiency virus exclusively in mature CD4(+) CD8(-) CD3(+) thymocytes: a critical role for tumor necrosis factor and interleukin-7. J. Virol. 73:7533-7542.

37. Lederman, M.M., and Valdez, H. 2000. Immune restoration with antiretroviral therapies: implications for clinical management. JAMA. 284:223-228.

38. Teixeira, L., et al. 2001. Poor CD4 T cell restoration after suppression of HIV-1 replication may reflect lower thymic function. AIDS. 15:1749-1756

39. Smith, C.J., et al. 2004. Factors influencing increases in CD4 cell counts of HIV-positive persons receiving long-term highly active antiretroviral therapy. J. Infect. Dis. 190:1860-1868.

40. Viard, J.P., et al. 2001. Influence of age on CD4 cell recovery in human immunodeficiency virusinfected patients receiving highly active antiretroviral therapy: evidence from the EuroSIDA study. J. Infect. Dis. 183:1290-1294.

41. Florence, E., et al. 2003. Factors associated with a reduced CD4 lymphocyte count response to HAART despite full viral suppression in the EuroSIDA study. HIV Med. 4:255-262.

42. Douek, D.C., et al. 1998. Changes in thymic function with age and during the treatment of HIV infection. Nature. 396:690-695.

43. Kaufmann, G.R., et al. 2005. Characteristics, determinants, and clinical relevance of $\mathrm{CD} 4 \mathrm{~T}$ cell recovery to $<500$ cells/microL in HIV type 1 -infected individuals receiving potent antiretroviral therapy. Clin. Infect. Dis. 41:361-372.

44. Kovacs, J.A., et al. 1995. Increases in CD4 T lymphocytes with intermittent courses of interleukin-2 in patients with human immunodeficiency virus infection. A preliminary study. N. Engl. J. Med. 332:567-575

45. Kovacs, R.G., and Aguayo, S.M. 1993. Images in clinical medicine. Superior vena cava syndrome. N. Engl. J. Med. 329:1007.

46. Levy, Y., et al. 1999. Comparison of subcutaneous and intravenous interleukin- 2 in asymptomatic HIV-1 infection: a randomised controlled trial. ANRS 048 study group. Lancet. 353:1923-1929.

47. Levy, Y., et al. 2003. Effects of interleukin-2 therapy combined with highly active antiretroviral therapy on immune restoration in HIV-1 infection: a randomized controlled trial. AIDS. 17:343-351.

48. Beq, S., et al. 2006. IL-7 induces immunological improvement in SIV-infected rhesus macaques under antiviral therapy. J. Immunol. 176:914-922.

49. Storek, J., et al. 2003. Interleukin-7 improves CD4 T-cell reconstitution after autologous CD34 cell transplantation in monkeys. Blood. 101:4209-4218.

50. Rosenberg, S.A., et al. 2006. IL-7 administration to humans leads to expansion of CD8+ and CD4+ cells but a relative decrease of CD4+ T-regulatory cells. J. Immunother. 29:313-319.

51. Wang, F.X., et al. 2005. IL-7 is a potent and proviral strain-specific inducer of latent HIV-1 cellular reservoirs of infected individuals on virally suppressive HAART. J. Clin. Invest. 115:128-137.

52. Schluns, K.S., and Lefrancois, L. 2003. Cytokine control of memory T-cell development and survival. Nat. Rev. Immunol. 3:269-279.

53. Kaech, S.M., et al. 2003. Selective expression of the interleukin 7 receptor identifies effector CD8 T cells that give rise to long-lived memory cells. Nat. Immunol. 4:1191-1198.

54. Carini, C., McLane, M.F., Mayer, K.H., and Essex,
M. 1994. Dysregulation of interleukin-7 receptor may generate loss of cytotoxic $\mathrm{T}$ cell response in human immunodeficiency virus type 1 infection. Eur. J. Immunol. 24:2927-2934.

55. Paiardini, M., et al. 2005. Loss of CD127 expression defines an expansion of effector CD $8+T$ cells in HIV-infected individuals. J. Immunol. 174:2900-2909.

56. Mastroianni, C.M., et al. 2001. Circulating levels of interleukin-7 in antiretroviral-naive and highly active antiretroviral therapy-treated HIV-infected patients. HIV Clin. Trials. 2:108-112.

57. Llano, A., et al. 2001. Interleukin-7 in plasma correlates with CD4 T-cell depletion and may be associated with emergence of syncytium-inducing variants in human immunodeficiency virus type 1positive individuals. J. Virol. 75:10319-10325.

58. Napolitano, L.A., et al. 2001. Increased production of IL-7 accompanies HIV-1-mediated T-cell depletion: implications for T-cell homeostasis. Nat. Med. 7:73-79.

59. Sasson, S.C., et al. 2006. Increased plasma interleukin-7 level correlates with decreased CD127 and Increased CD132 extracellular expression on T cell subsets in patients with HIV-1 infection. J. Infect. Dis. 193:505-514.

60. Dunham, R.M., et al. 2008. CD127 and CD25 expression defines CD4+ $T$ cell subsets that are differentially depleted during HIV infection. J. Immunol. 180:5582-5592.

61. Silvestri, G., and Feinberg, M.B. 2003. Turnover of lymphocytes and conceptual paradigms in HIV infection. J. Clin. Invest. 112:821-824.

62. McCune, J.M. 2001. The dynamics of CD4+ T-cell depletion in HIV disease. Nature. 410:974-979.

63. Douek, D.C., et al. 2000. Assessment of thymic output in adults after haematopoietic stem-cell transplantation and prediction of T-cell reconstitution. Lancet. 355:1875-1881.

64. Ducrey-Rundquist, O., Guyader, M., and Trono, D. 2002. Modalities of interleukin-7-induced human immunodeficiency virus permissiveness in quiescent T lymphocytes. J. Virol. 76:9103-9111.

65. Scripture-Adams, D.D., Brooks, D.G., Korin, Y.D., and Zack, J.A. 2002. Interleukin-7 induces expression of latent human immunodeficiency virus type 1 with minimal effects on T-cell phenotype. J. Virol. 76:13077-13082.

66. Avettand-Fenoel, V., Boufassa, F., Galimand, J., Meyer, L., and Rouzioux, C. 2008. HIV-1 DNA for the measurement of the HIV reservoir is predictive of disease progression in seroconverters whatever the mode of result expression is. J. Clin. Virol. 42:399-404.

67. Agence nationale de recherches sur le sida et les hépatites virales. 2008. ANRS scale to grade the severity of adverse events in adults. http://www.anrs.fr/ index.php/anrs/content/download/2242/12805/ file/ANRS-GradeEI-V1-En-2008.pdf.

68. Losso, M., Abrams, D., and INSIGHT ESPRIT Study Group. 2009. Effect of interleukin-2 on clinical outcomes in patients with a CD4+ cell count of 300/mm3: primary results of the ESPRIT study. Abstract no. $90 \mathrm{aLB}$ presented at the 16 th Conference on Retroviruses and Opportunistic Infections. February 8-11. Montreal, Quebec, Canada.

69. Levy, Y., and SILCAAT Sci Committee. 2009. Effect of interleukin-2 on clinical outcomes in patients with CD4+ cell count 50 to $299 / \mathrm{mm} 3$ : primary results of the SILCAAT study. Abstract no. 90bLB presented at the 16th Conference on Retroviruses and Opportunistic Infections. February 8-11. Montreal, Quebec, Canada. 